\title{
Best practice for groundwater quality protection
}

\author{
Yongxin $\mathrm{Xu}$ \\ Department of Earth Sciences at the University of the Western Cape, South Africa
}

Phil Hobbs

Council for Scientific and Industrial Research, Pretoria, South Africa

Ken Bradbury

Wisconsin Geological and Natural History Survey, Madison, WI, USA

Nick Robins

Formerly British Geological Survey, UK

Thokozani Kanyerere, Eberhard Braune \& Jaco Nel

Department of Earth Sciences at the University of the Western Cape, South Africa

\subsection{GENERAL INTRODUCTION}

A strategic framework discussed above should be seen as an important premise on which international groundwater best practice is promoted and implemented. Currently, there are only limited references of what constitutes good groundwater management in Africa. What has been published addresses mainly resource quantity and quality, resource use and resource vulnerability (UNEP, 1996, Foster et al., 2006, Xu and Usher, 2006). For rural water supply, the reader may be referred to a guide book on developing groundwater (MacDonald et al., 2005). Other, more readily available indicators of good management could be expressions of the available information on groundwater, e.g. how current records are, how regularly published and how well expressed in predictive models. However, with the increasing devolution of water resources management to lower levels, in particular river basin organizations, clear guidance will also become increasingly important for the full spectrum of management actions.

A compendium of 'best practice' directions is probably the closest indicators of good management we will come to, given the complex management environment touched on above. An example of such an approach has been an evaluation of SADC groundwater management under IWRM principles (Braune et al., 2007). A very good summary of the scope and practice of groundwater management can be found in The World Bank Briefing Note Series on Groundwater Management (World Bank, 2002). A major step towards putting in place regional best practice has been the 'Guidelines for Groundwater Development in the SADC Region' (SADC WCSU, 2000).

In practice, the best practice has to adapt to local conditions for the intended benefit. The best practice ranges from borehole location, drilling, construction and equipment, environmental protection, community participation etc. In this chapter, the focus is placed on some key practices that all have a bearing on a sustainable groundwater supply. The sections that follow include borehole construction standards, demarcation of water source protection areas, management of on-site sanitation and other related measures. 


\subsection{SOUTH AFRICAN BOREHOLE GUIDELINES}

Establishing a water supply borehole is a combination of science, trade and art with many and varied nuances that often surprise even the most experienced of geoscientists, geotechnicians and groundwater practitioners. The adage of never being too old to learn enjoys great application in this field, and has mostly to do with the relative inscrutability of the resource being targeted. It is sometimes knowledge of the devil in the detail that determines the difference between success and failure. The literature, both published and electronic, abounds with often exhaustive material on the topic. It would be easy to merely repeat the subject matter in this contribution which, due to length limitations, would necessarily reduce such repetition to largely generic material. Instead, this contribution discusses specific aspects and components that often represent the devil in the detail which, if not recognised or given attention, can lead to costly failure of the process. Included amongst these are contracts/agreements, the supervision of activities, consideration of materials and equipment, recognition of anomalous circumstances, safeguarding of the resource and borehole straightness considerations. If the information conveyed in this chapter contributes to the trouble-free and successful establishment of just a single safe water supply borehole, it will have served its purpose.

\subsubsection{Introduction}

The process of establishing a water supply borehole represents a significant investment in both financial terms and in faith. The financial terms relate to the cost of construction of the facility and, if successful, its subsequent proving and equipping. The faith aspect relates to the anticipation (hope?) that the borehole will be successful, an intangible factor that depends not only on the competence of the person(s) responsible for marking the site of the borehole, but also on the competence of the contractor(s) who will be responsible for seeing the process through to its conclusion. In both instances, competence can be measured by the knowledge, experience and integrity of the parties involved.

The contracted services are provided firstly by the drilling Contractor, whose task it is to sink and construct the borehole. If successful, a test pumping Contractor will be employed to determine the optimal yield of the borehole. Finally, an equipping Contractor will install a pump and fit the ancillary infrastructure to deliver the groundwater on surface. Ideally, these service providers will function under the supervision of a (preferably) experienced geoscientist or geotechnician who will gauge the terms of reference that inform each of these activities as integral parts of a consummate whole.

This contribution explores only a few of many aspects that represent the devil in the detail of establishing a successful and safe water supply borehole. It is the author's opinion that these receive less attention than they deserve, even though neglect thereof can lead to costly failure.

\subsubsection{Relevant literature}

It is appropriate to commence this contribution with a synopsis of relevant literature that informs the subject. The definitive text on borehole drilling and construction is considered by many in the groundwater industry to be the 1089-page publication Groundwater and Wells (Driscoll, 1986). This book has recently been released in its 3rd edition (Driscoll, 2008). Other publications that provide detailed and comprehensive information on the topic are the Manual of water well construction practices published by the United States Environmental Protection Agency (EPA, 1975), and the AWWA Standard for Water Wells published by the American Water Works Association (AWWA, 2006). Another useful source is the publication Minimum Construction Requirements for Water Bores in Australia (LWBC, 2003) funded by the Australian Land and Water Biodiversity Committee (LWBC). This publication is clear in its aim to ensure, amongst others, “... that the very large investment in bore construction be 
protected by proper construction methods." The explosion in electronic knowledge brokering represented by the world wide web and the internet has itself spawned freely available literature on the topic (e.g. FCI, 2004; Lifewater, 2004) to those with access to e-communication services.

In a regional context, the Water Sector Coordination Unit of the Southern African Development Community (SADC) commissioned the development of minimum common standards for groundwater development in the SADC region (SADC, 2000a). This project also incorporated country-based situation analysis reports (SADC, 2000b) which report and discuss documentation that informs standards, guidelines and manuals for groundwater development as exist for SADC member states. In South Africa, the Department of Water Affairs and Forestry (DWAF) produced guidelines for groundwater resource development in support of the community water supply and sanitation programme (Hobbs and Marais, 1997), whilst Sami and Murray (1998) also discuss borehole design, construction and development in a rural water supply context. The South African Bureau of Standards (SABS) developed a 9-part set of South African National Standards for the groundwater industry, of which Part 2 (SANS, 2003a) has direct relevance to this topic. It is evident, therefore, that the subject is comprehensively covered in readily available literature. As a consequence, this contribution refrains from repeating especially generic subject matter that can be sourced elsewhere.

\subsubsection{Contracts and agreements}

The process of establishing a water supply borehole is as much a science and a trade as an art. The science and trade find expression in knowing what drilling method and technique to employ in specific hydrogeologic conditions and employing it 'by the book'. The art finds expression in the practices (often and typically innovative) employed to achieve success when the science and trade fails.

Two parties are instrumental in the process. The Owner (Client/Purchaser) who commissions a Contractor to perform the work. The Owner may choose to appoint a third party, the Representative, to supervise and instruct the Contractor on their behalf. The Table 4.1 describe the possible inter-relationship between, and associated implications for, the parties concerned.

A key element that underpins the process is the professional relationship that exists between the Contractor and the Representative. Ideally, this relationship is based on mutual trust in the competencies of the respective parties. Further, that this relationship fosters their functioning as a team whose common goal is the establishment of a serviceable and efficient groundwater

Table 4.1. The possible inter-relationship between, and associated implications for, the parties concerned.

\begin{tabular}{ll}
\hline Owner/Contractor/Representative permutation & Implication \\
\hline $\begin{array}{c}\text { Owner employs a Contractor directly, and does } \\
\text { not employ a Representative }\end{array}$ & $\begin{array}{c}\text { Contractor fulfils the dual role of Contractor } \\
\text { and Representative. Owner accepts that the }\end{array}$ \\
& Contractor will deliver a serviceable product \\
& Owner liable for cost of the contracted service. \\
Owner employs a Contractor and a & Representative assumes responsibility for \\
Representative separately & Contractor delivering a serviceable product. \\
& Owner liable for cost of the contracted and \\
& representation services. \\
Owner employs a Representative, who in turn & Representative assumes responsibility for \\
employs the necessary Contractor(s) & Contractor delivering a serviceable product. \\
& Representative liable for cost of the contracted \\
& service(s). Owner liable for cost of the \\
& representation and associated services. \\
\hline
\end{tabular}


supply facility. Although perhaps a contradiction in this context, it is an absolute imperative that the drilling and construction activity, and also the test pumping activity for that matter, be underpinned by a legal contract document that clearly spells out the terms and conditions of the service(s) to be provided. This aspect of the process normally finds a place towards the end of texts on the subject, when in fact it is one of the first aspects to be given attention.

There are numerous standard 'off the shelf' contract documents available, for example that provided in Driscoll (1986) and the Standard Form Drilling Agreement obtainable from the Borehole Water Association of Southern Africa (BWA, 2009). Driscoll (1986) devotes 27 pages to a discussion of borehole drilling and construction specifications and contract problems. To the author's knowledge, the document that covers this aspect the most comprehensively is that of the United States EPA (1975).

It is often what does not appear in the contract or agreement that gives rise to acrimony between parties in the event of something going wrong. An unsuccessful borehole is often cause for unhappiness due to the considerable yet fruitless expense it represents. In most instances, such circumstances also do not signify neglect or the lack of applying due diligence by any party concerned. It is simply beyond reasonable expectation for any party involved with the establishment of a water supply borehole to guarantee its expected or required water-producing success. This is part and parcel of the relatively inscrutable nature of the resource mentioned previously.

\subsubsection{Supervision of activities}

Although full time supervision of the process represents the ideal, the LWBC (2003) recommends that "The client, or representative, should be on site for a substantial amount of the construction period ...". With reference to the tasks of the project coordinator in a drilling programme, the FCI (2004) states that "Actually you should be in the field most of the time during drilling". Unfortunately the financial cost and availability of personnel invariably reduces this service to shorter and often infrequent visits to the site of operations. Seen against a background where drilling contractors "... are not renowned for the quality of their paperwork". (Entrepeneur.com, 2009), these circumstances place an added burden on the Contractor(s) to report as comprehensively and honestly as possible on their operational activities. This will vary from accurately recording time-based parameters such as bit penetration rate during drilling and water level drawdown/recovery during test pumping, to event-based parameters such as water strike depth and yield during drilling, and equipment breakdowns during test pumping.

Perhaps more important than any other aspect, reporting will also include recording circumstances that may compromise the serviceability of the facility at the time or in the future, and communicating such to the Owner or Representative at the earliest opportunity. This will typically include circumstances that constitute a material defect or impediment that compromises the successful commissioning of the facility for its intended purpose. Due to the nature of the facility, such defects and impediments are typically 'invisible', even to the trained eye, from surface. A prime example of this is where equipment, e.g. drill bit, spanner, pump, etc., is lost or left behind in the borehole.

A non-negotiable clause in a contract or agreement must therefore stipulate that the Contractor vacating the site of operations leaves such site, and in particular specific installations such as a borehole, in the same condition as prevailed when first occupying the site/ installation. In the case of the drilling Contractor, this might simply entail proving that the borehole is capable of accepting a pump of a given diameter to a given depth, since it is not generally incumbent on this service provider to prove the potential yield of the borehole. Apart from the similar obligation imposed on the next 'occupying' Contractor, it is also in the interest of the latter to establish the exact condition of the installation when first occupying the site. In the case of the test pumping Contractor, this will entail proving that the borehole is capable of accepting a pump of a given diameter to a specified depth both before and 
after test pumping of the borehole. The initial proving will establish the serviceability of the borehole for test pumping purposes, whereas the final proving will establish the serviceability of the facility for equipping. The given diameter must be the same or greater than that of the pump which will be used for testing the borehole. The SADC (2000a) document recommends that "... the maximum pump diameter should not be more than $80 \%$ of the finished diameter of the borehole at the depth where pump installation is planned". In the case of both the drilling Contractor and the test pumping Contractor, this proving is readily achieved with a straightness/alignment test (section 7).

\subsubsection{Materials and equipment}

Countries such as Australia and America which enjoy a longer history of mechanised water borehole drilling than any on the African continent, have developed standards for materials and practices that are specific to this industry. The American Society for Testing and Materials (ASTM) standards D2855-96 (ASTM, 2002) and F480-06b (ASTM, undated), and the Australian AS/NZS 1477:1999 standard for PVC pipes and fittings for pressure applications, serve as examples. In a regional context, the SADC (2000a) document refers to the SABS 966:1998 standard for uPVC pipe as having the minimum characteristics for use as borehole casing. The SANS 10299-2:2003 (SANS, 2003a) standard, however, does not reference a specification in this regard; it only specifies threads, and then in accordance with ASTM F480 (ASTM, undated) or BS 879-2:1988 (BS, 1988). The SAPPMA (2006) technical manual provides information (some of which is replicated in the Table 4.2) on UPVC and $\mathrm{mPVC}$ pipe as produced in South Africa, but does not refer to the collapse strength from external pressure of this pipe beyond stating that PVC "cannot withstand crushing". It is worth noting that some casing/screen manufacturers may use specially manufactured uPVC pipe with 'odd' specifications to those shown, e.g. Class 12 equivalent ( $8.5 \mathrm{~mm}$ sidewall thickness) pipe with an outside diameter of 168 or $186 \mathrm{~mm}$.

Perhaps few aspects illustrate the devil in the detail adage better than factors which influence the application and use of PVC (polyvinyl chloride) pipe as casing in the construction of a borehole. The groundwater industry has traditionally favoured uPVC (unplasticized PVC) pressure pipe. Technological developments in pipe manufacturing processes have, however, produced mPVC (modified PVC) and oPVC (oriented PVC) pressure pipe with thinner sidewall thicknesses than uPVC pipe of the same class. This characteristic recognises the superior mechanical property of $\mathrm{mPVC}$ and oPVC pipe to withstand internal pressure. In the borehole

Table 4.2. Some information from the SAPPMA (2006) technical manual.

\begin{tabular}{|c|c|c|c|c|c|c|c|c|c|}
\hline & \multirow{3}{*}{$\frac{\text { Class }}{\text { Type }}$} & \multicolumn{8}{|c|}{ Inside diameter and wall thickness (WT) (mm) } \\
\hline & & \multicolumn{2}{|l|}{9} & \multicolumn{2}{|l|}{12} & \multicolumn{2}{|l|}{16} & \multicolumn{2}{|l|}{20} \\
\hline & & uPVC & $\mathrm{mPVC}$ & $\mathrm{uPVC}$ & $\mathrm{mPVC}$ & uPVC & $\mathrm{mPVC}$ & uPVC & $\mathrm{mPVC}$ \\
\hline \multirow{10}{*}{ 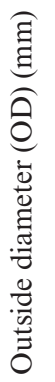 } & OD 125 & 116 & 118 & 113 & 116 & 109 & 114 & 104 & 111 \\
\hline & WT & 4.5 & 3.5 & 6.0 & 4.5 & 8.0 & 5.5 & 10.5 & 7.0 \\
\hline & OD 140 & 129 & 133 & 126 & 130 & 122 & 127 & 118 & 124 \\
\hline & WT & 5.5 & 3.5 & 7.0 & 5.0 & 9.0 & 6.5 & 11.0 & 8.0 \\
\hline & OD 160 & 148 & 151 & 144 & 149 & 139 & 145 & 134 & 142 \\
\hline & WT & 6.0 & 4.5 & 8.0 & 5.5 & 10.5 & 7.5 & 13.0 & 9.0 \\
\hline & OD 200 & 185 & 190 & 180 & 186 & 174 & 182 & 168 & 178 \\
\hline & WT & 7.5 & 5.0 & 10.0 & 7.0 & 13.0 & 9.0 & 16.0 & 11.0 \\
\hline & OD 250 & 231 & 237 & 225 & 233 & 218 & 227 & 210 & 222 \\
\hline & WT & 9.5 & 6.5 & 12.5 & 8.5 & 16.0 & 11.5 & 20.0 & 14.0 \\
\hline
\end{tabular}


application context, however, it is rather the ability of pipe to withstand external pressure such as that created by substantial differences in the water level inside the cased borehole compared to those outside the cased borehole during pumping, that is important. Under these circumstances, uPVC pipe has enjoyed favour due to its superior strength, stiffness and resistance to external pressure than the other types of PVC pipe. This does not mean that $\mathrm{mPVC}$ pipe is unsuitable for use as borehole casing. It is probable that a higher class (greater wall thickness) mPVC pipe exists which offers greater strength, stiffness and ability to withstand external pressure than a lower class uPVC pipe. The interested reader can find more information in this regard in Vinidex (2004) and PIPA (2007a; 2007b). It is these circumstances, however, which indicate that an awareness and appreciation for the various types of uPVC pipe and their mechanical properties is important.

Another aspect regarding the use of PVC pipe as borehole casing that warrants discussion, is the joining of sections of this pipe. The SANS 10299-2:2003 (SANS, 2003a) standard allows only screw-threaded joints, forbidding solvent welded socket joints. The SADC (2000) document also states that "... threaded couplings are required ...". This is in contrast to Driscoll (1986) and the EPA (1975) and LWBC (2003) documents, which sanction both solvent welded and threaded-and-coupled joints. The LWBC (2003) document is clear both in the type of cement to be used and that it should be "... applied evenly to both spigot [male] and socket [female] ends, applied to the socket end first". The Lifewater (2004) document recommends roughening the joint surfaces with sandpaper prior to the application of solvent cement. In regard to supporting the joint while the solvent cement cures, the LWBC (2003) document instructs that "... only stainless steel screws are to be used", and that "Care must be taken to ensure the screws do not protrude internally". No mention is made of using pop rivets to secure the joint. Since general purpose 'blind' pop rivets are typically manufactured from aluminium, the process of passivation whereby corrosion of the rivet is mitigated by the formation of a protective aluminium oxide coating implies a greater longevity and, consequently, less risk of it corroding away entirely to leave a hole in the joint. Any concern that may exist for the use of pop rivets in securing joints must therefore relate to the internal protrusion of the 'buck-tail' (deformed) end. This end may be sheared off by any equipment inserted or extracted from the borehole, leading to the possibility that the hole occupied by the mandrel could let material such as fine sand or contaminant enter the bore. Under these circumstances, the use of pop rivets is not encouraged so as to eliminate this devil in the detail.

The requirement that the pumping rate maintained during the constant discharge testing of a borehole should not vary by more than $\sim 5 \%$ over the duration of the pumping period (EPA, 1975) often precipitates the preferred use of a positive displacement type pump for this activity (Hobbs and Marais, 1997; SADC, 2000). It can be argued that specification of the requirement itself is sufficient, irrespective of how and with what equipment it is achieved, so long as indisputable proof of meeting the requirement is provided.

\subsubsection{Aanomalous circumstances}

Every so often during borehole drilling and construction, anomalous circumstances arise that warrant caution and which, if not heeded, could have severe consequences for the successful completion of the facility. An example hereof is where an inordinate amount of material is returned from the borehole during drilling, compared to the theoretical volume of the borehole as a function of drilling diameter and depth of advancement. This is more likely to occur during rotary percussion drilling (even if a surfactant is used) than during direct circulation mud rotary drilling. It is also often accompanied by a slower penetration rate than might be expected for ostensibly 'soft rock' strata, since the material produced is often fine grained, i.e. sandy or silty material as opposed to the rock cuttings/chips obtained from hard, competent strata. It is the author's experience that glauconitic sandstone in particular is prone to such 'behaviour'. These circumstances indicate the likely development of cavernous conditions that might be accompanied by caving or slumping of the borehole sidewall. 
This will almost certainly impact on the final construction of the borehole by reducing the depth of the facility or preventing the insertion of casing to the required depth.

The Table 4.3 serves to quantify this phenomenon by relating metres drilled and diameter to the theoretical volume of material that should be returned from a bore intersecting fine- to medium-grained soft rock sandstone using the air rotary percussion drilling method. Noticeably more material than indicated would be anomalous and sufficient reason to investigate the circumstances and assess the situation.

\subsubsection{Straightness and verticality}

Borehole straightness (alignment) and verticality (plumbness) are not synonymous concepts. A perfectly vertical borehole is necessarily straight, but a perfectly straight borehole is not necessarily vertical. These concepts are illustrated in Figure 4.1. The consensus of opinion in the groundwater industry is that straightness, within limits of course, is more important than verticality. In the author's experience, it is only the diviner who has targeted a 'water vein' of a specific geometry at a presupposed depth who finds in non-verticality a ready excuse for a failed borehole. Nevertheless, straightness is more likely to be achieved if the drilling Contractor uses a drill collar and stabilizer rods at the working end of the drill string, i.e. immediately behind/above the drill bit, than if these are absent.

The determination of borehole straightness is much more readily achieved than verticality. It merely requires lowering a device (often referred to as a dummy) of specific dimensions under its own weight down a borehole and bringing it back to surface. The free and unfettered movement of the device in its passage down and back up the borehole is sufficient proof of straightness.

The dimensions of a borehole dummy comprise a specified length and a variable diameter determined by the smallest diameter of the borehole being surveyed for straightness. The literature sources consulted specify different lengths, e.g. SANS (2003a) specifies a length of at least $5 \mathrm{~m}$, Hobbs and Marais (1997) and SADC (2000) specify $6 \mathrm{~m}$, whereas EPA (1975), Driscoll (1986) and LWBC (2003) specify $12 \mathrm{~m}$. The latter dummy straddles two standard lengths $(6.1 \mathrm{~m})$ of casing when centred over a casing joint. It therefore provides a much stricter survey than the shorter dummies, which straddle only $\sim 50 \%$ of a standard length of casing when centred over a casing joint. The SANS 10299-2:2003 (SANS, 2003a) standard specifies the most lenient straightness requirement, and the outcome must be gauged against this knowledge.

The second dimension, that of diameter, defines the tolerance between the outside diameter of the dummy and the inside diameter of the borehole being surveyed. In this regard, the EPA (1975) offers two tolerances, namely $\leq 13 \mathrm{~mm}$ for a borehole diameter $\leq 254 \mathrm{~mm}$, and $\leq 25 \mathrm{~mm}$ for a borehole diameter $\geq 305 \mathrm{~mm}$. The LWBC (2003) distinguishes between a tolerance of $20 \%$ when using a rigid dummy and $15 \%$ when using a test 'dolly', where a dummy is simply a length of pipe (Figure 4.1) and a test 'dolly' a rigid tube forming an axis onto

Table 4.3. Relation among types of strata, metres drilled and diameter to the theoretical volume of material that should be returned from a bore intersecting fine- to medium-grained soft rock sandstone using the air rotary percussion drilling method.

\begin{tabular}{llllll}
\hline & $\begin{array}{l}\text { Nominal bore } \\
\text { diameter } \\
(\mathrm{mm})\end{array}$ & $\begin{array}{l}\text { Volume per } \\
\text { metre } \\
(\mathrm{L})\end{array}$ & 21 & $\begin{array}{l}\text { Packing } \\
\text { coefficient }\end{array}$ & Equivalent volume \\
\cline { 5 - 6 } & $1 \mathrm{~L})$ & $0.8(80 \%)$ & 26 & $\sim 1.3$ \\
\hline $\begin{array}{l}\text { Fine to medium- } \\
\text { grained soft rock }\end{array}$ & 204 & 33 & & 41 & $\sim 2$ \\
sandstone & 254 & 51 & & 64 & $\sim 3$ \\
\hline
\end{tabular}

$* 1$ bucket $=20 \mathrm{~L}$. 

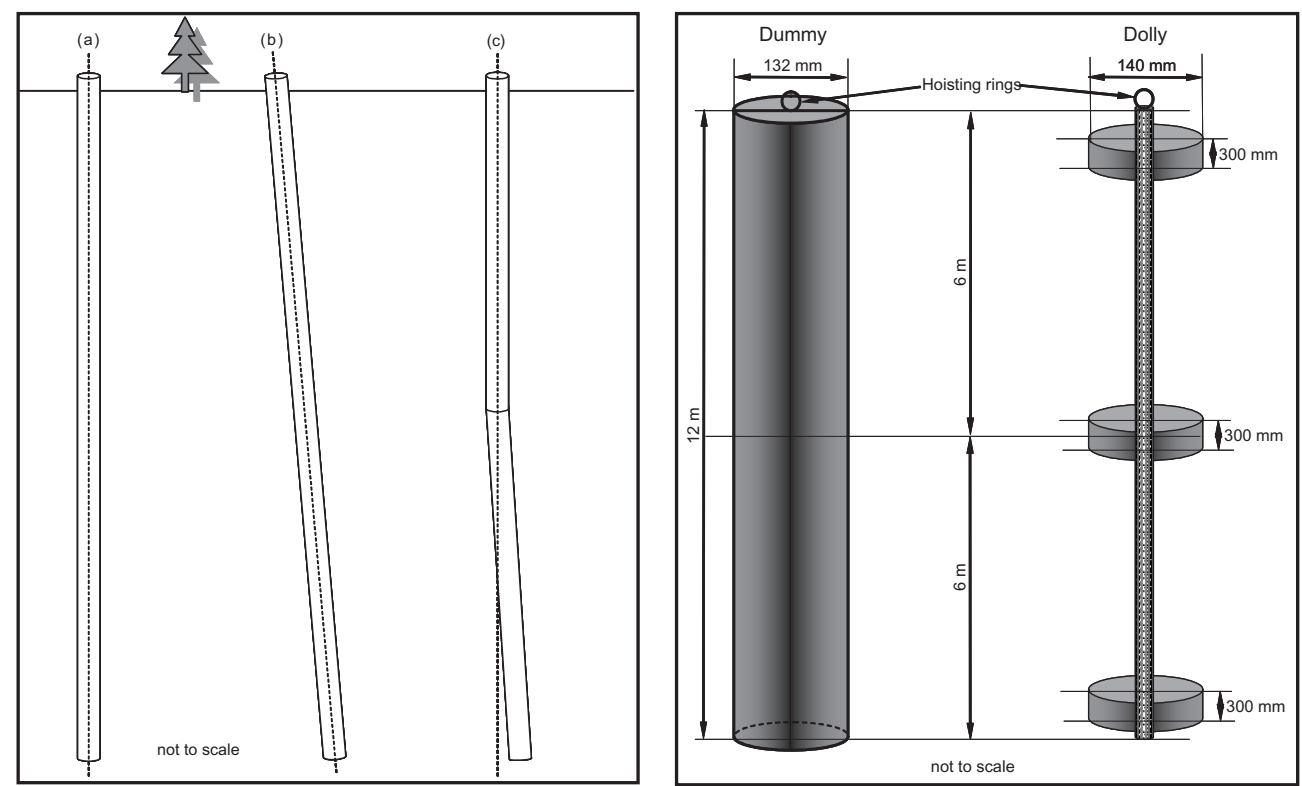

Figure 4.1. A diagrammatic representation of a borehole that is straight and plumb (a), straight but not plumb (b), and neither straight nor plumb (c); b, diagrammatic representation of a dummy and a test dolly as are suitable for surveying the straightness of a $165 \mathrm{~mm}$ nominal diameter borehole according to LWBC (2003) specifications. The $300 \mathrm{~mm}$ long pipe sections on the dolly derive from SADC (2000).

which three pipe sections, one at each end and one in the centre, are attached (Figure 4.1). Both Hobbs and Marais (1997) and the SADC (2000) specify a tolerance of $10 \mathrm{~mm}$ less than the smallest finished diameter of the borehole being surveyed. On a $165 \mathrm{~mm}$ nominal diameter bore, this translates to a diameter of $145 \mathrm{~mm}$, which is similar to that prescribed by the LWBC (2003) as shown in Figure 4.1 for a 'dolly' test.

\subsubsection{Protecting the resources}

It is an absolute imperative in potable water supply applications that a borehole installation not only provides clean and safe drinking water, but also safeguards the resource from possible contamination (Xu and Usher, 2006). This is especially relevant in a rural community water supply context (Braune and $\mathrm{Xu}, 2006$ ). Whilst the facility cannot secure this for the surrounding environment, access to the resource via the borehole itself is a possibility that must be eliminated. This is achieved by grouting the annular space (annulus) between the borehole sidewall and the surface casing with impervious material, typically neat cement, a sand/ cement mixture or concrete, to form a sanitary seal. The construction of a proper sanitary seal must be a mandatory component of every water supply borehole. As with other aspects discussed in this chapter, the literature shows significant variation in the recommended specifications for and design of sanitary seals. The following recommendations sourced from the literature (EPA, 1975; Driscoll, 1986; Ferro and Bouman, 1987; SADC, 2000a; LWBC, 2003; Lifewater, 2004), are put forward as representing 'best practice' in this regard.

The primary consideration is the depth to which the sanitary seal must extend below surface. Most of the source literature agrees on a minimum depth of $5 \mathrm{~m}$, but all qualify this on the basis of the nature and extent of the near surface material and the proximity of compromising facilities such as on-site sanitation infrastructure. The devil in the detail of this aspect is the requirement that the annular space be sufficiently large and open to receive the grout 
mixture without restriction for the entire length of the sanitary seal, being completely filled with grout on completion. Further, that the sanitary seal rests on some form of underlying annular fill material. In the case of open borehole completions, this will generally be bedrock into which the surface casing is embedded. Since drill cuttings accumulating around the borehole on surface are easily flushed into the annulus during drilling, this must be flushed clean before introducing the grout. An annular space of 50 to $100 \mathrm{~mm}$ is considered sufficient (Driscoll, 1986). This necessarily requires careful consideration of the size of the borehole and final surface casing. For example, a nominal $204 \mathrm{~mm}$ diameter borehole fitted with $160 \mathrm{~mm}$ outside diameter PVC casing (section 5) will provide a barely acceptable annular space of roughly $45 \mathrm{~mm}$.

Grout mixtures regarded as suitable include cement/water, cement/bentonite/water and cement/sand/water. The use of old cement, recognised by its lumpy and clotted nature, is unacceptable. Simply pouring the grout slurry evenly into the annulus is only acceptable where the grout interval is visibly open, dry and does not exceed some $9 \mathrm{~m}$ in depth below surface. It is preferable to introduce the grout mixture from the bottom upwards using a tremie pipe with a nominal diameter of $38 \mathrm{~mm}$ and a funnel. The tremie pipe is withdrawn as the annulus fills with grout. The mixing ratios presented in Table 4.4 define ingredient quantities for the respective grout mixtures (after EPA, 1975; Driscoll, 1986; LWBC, 2003).

A borehole which is no longer in use (abandoned or decommissioned) and has been left open, similarly represents an unacceptable risk and potentially lethal threat in its environment. It provides an excellent pathway for pollutants to enter the subsurface and contaminate the groundwater resource. Further, erosion of the borehole at surface might enlarge the opening sufficiently for a person to fall into. As recently as 2 November 2008, a 3-year old boy died under tragic circumstances after falling into an abandoned borehole on a smallholding near Polokwane/Pietersburg, South Africa (Louw-Carstens, 2008a; 2008b). The abandonment of a borehole is addressed in most of the literature sources referenced in section 2 . The SANS 10299-9:2003 (SANS, 2003b) standard is specific to this activity. As in the case of sanitary seals, the following recommendations are put forward as representing 'best practice' in this regard. Most of the source literature appears to borrow substantially from the AWWA (2006) recommendations for sealing abandoned boreholes.

The objective is to re-establish as closely as reasonably possible, the hydrogeologic conditions that existed before construction of the borehole. This necessarily requires knowledge

Table 4.4. Relation among types of strata, metres drilled and diameter to the theoretical volume of material that should be returned from a bore intersecting fine- to medium-grained soft rock sandstone using the air rotary percussion drilling method.

\begin{tabular}{llllll}
\hline $\begin{array}{l}\text { Grout mixture } \\
\text { per 40 kg bag } \\
\text { of cement) }\end{array}$ & $\begin{array}{l}\text { Volume of } \\
\text { water } \\
(\mathrm{L})\end{array}$ & $\begin{array}{l}\text { Quantity of } \\
\text { bentonite } \\
(\mathrm{kg})\end{array}$ & $\begin{array}{l}\text { Quantity of } \\
\text { clean sand* } \\
(\mathrm{kg})\end{array}$ & $\begin{array}{l}\text { Volume of } \\
\text { grout made } \\
(\mathrm{L})\end{array}$ & $\begin{array}{l}\text { Length of } \\
\text { annulus filled** } \\
(\mathrm{m})\end{array}$ \\
\hline Cement/water & 20 & - & - & $\sim 33$ & 3.0 \\
& 25 & - & - & $\sim 38$ & 3.5 \\
& 30 & - & - & $\sim 43$ & 3.9 \\
$\begin{array}{l}\text { Cement/bentonite/ } \\
\text { water*** }\end{array}$ & 40 & $0.8(2 \%)$ & - & & \\
& 50 & $1.6(4 \%)$ & - & $\sim 53$ & 4.7 \\
& 60 & $2.4(6 \%)$ & - & $\sim 63$ & 5.7 \\
Cement/sand/water & 20 & - & 60 & $\sim 60$ & 6.7 \\
\hline
\end{tabular}

* Preferably a fine- to medium-grained sand $(0.1-1.0 \mathrm{~mm})$ washed free of clay or organic material. **Annular space $=50 \mathrm{~mm}$ plus $25 \%$ allowance for washout or loss of grout into formation. *** Best practice recommends mixing bentonite and water before adding cement (Driscoll, 1986; LWBC, 2003). 
of at least the depth, thickness and water-bearing properties of the strata intersected. In the absence of a drilling record (section 4), some of this information may be re-constructed from a downhole geophysical survey and camera inspection of the borehole. Unfortunately the expense and relative scarcity of such a service are prohibitive factors in such an application. Prior to sealing, the borehole must in any event be checked for depth (plumbed) and any obstructions (section 7) that may compromise the objective. It is advisable to also remove any casing, and especially surface casing, from the borehole. Boreholes that intersect an unconfined or semi-unconfined aquifer must be sealed by placing cement grout or concrete from the bottom upward in a manner that prevents segregation of the material. In the case of a semi-confined or confined aquifer, the borehole can be filled with clean sand, gravel or aggregate to within $5 \mathrm{~m}$ of surface, and sealing the remainder with cement grout or concrete to surface. Finally, the methods and materials used to achieve successful abandonment, as well as the various dimensional parameters such as quantities, depth intervals, etc. must be recorded for future reference.

\subsubsection{Safety}

Unfortunately, loss of human life is not associated only with abandoned boreholes. In an assessment of fatalities among humanitarian workers in Africa, Sheik et al. (2000) report that "Unintentional violence was in some cases related to carelessness, such as running into a spinning airplane propeller or being killed during borehole drilling". Although the nature of the latter instances is not reported, the blanket association thereof with carelessness (as opposed to accident) is questionable. Nevertheless, the nature of any work which involves the handling and lifting of heavy equipment and material poses a safety risk, and borehole drilling is no exception. Although it is the responsibility of the drilling Contractor to ensure that basic safety measures such as cordoning off the work area and the wearing of hardhats, gloves and steel-toe footwear are adhered to, the duty rests on all parties concerned to ensure that this is enforced. The greater concern, especially when working in rural areas where the sinking of a borehole enjoys substantial spectator value, is for the safety of the local populace who may crowd the site and encroach on the work area.

\subsubsection{Conclusions}

This contribution touches on only a few aspects associated with the establishment of a water supply borehole, yet even in these the considerable complexity and variation that exists in the process is highlighted. Further, the measure of inconsistency that exists in regard to standards, specifications and even guidelines is apparent. These circumstances impose considerable obligations on the various service providers involved in the process to ensure that a serviceable groundwater supply facility is delivered. More so, they draw attention to the need for a uniform and consistent set of guidelines that may serve as a definitive reference for geoscientists, geotechnicians and groundwater practitioners operating on the African continent. The Australian (LWDC, 2003) example shows that this does not need to be a mammoth and hugely detailed document. The devil in this detail, however, is reaching an acceptable measure of consensus within and across the groundwater industry.

\subsection{GROUNDWATER PROTECTION GUIDELINES}

Once groundwater is tapped as source of water supply, its protection merges as a top priority for the sustainable utilization. On-site sanitation can contaminate nearby water points, a commonsense statement but a piece of advice that is often overlooked. The worst situation is that of a pit latrine just up-hydraulic gradient from a shallow well or borehole. Commonsense 
also tells us that the wellhead should be protected from surface waters and fenced to avoid access by animals. Simple though these rules might be there remains an important task for hydrogeologists in particular and field workers in general to get these messages across to villagers, their Chief, Headman and Water Committee. Disease risks from drinking water infected with faecal coli and viral contaminants include hepatitis, poliomyelitis, diarrhoeal diseases, typhoid, dysentery and cholera.

While the resource protection entails the assessment of aquifer vulnerability and pollutant loading at the scale of an aquifer, the source protection requires the best practice measures that can be realistically implemented around water source points. The latter would be implemented based on the differentiated principle (Xu and Reyders, 1995). A high level of the protection measures should be accorded to aquifers of the high risk associated with the heavily loading contaminants and high vulnerability. In addition the strategic value of the aquifer should also be considered as one of important requirements for accordance of high level protection. This section will introduce three important measures of groundwater source protection including safe distance, borehole protection (wellhead protection) zoning and spring protection.

\subsubsection{Basic approaches}

To guarantee a good quality water supply entails effort in many aspects ranging from borehole siting, borehole construction and pump installation to demarcation of protection zones around a borehole or wellfield (borefield). This section places an emphasis on the latter. Though protection zoning around a well or borehole is widely practised in some developed countries, it proved difficult in its adoption locally in southern Africa and in other parts of the continent. Taking into account the developing nature of socio-economic infrastructures in Africa, this section first introduces a simple minimum distance (or safe distance) as an important measure against well/borehole contamination for Africa. Then the concept of a protection zone is presented for possible implementation wherever feasible.

\subsubsection{Concept of safe distance}

The safe distance or called minimum distance or sometimes termed optimum distance was loosely defined as separation distance between drinking water supply wells and sources of potential or existing pollution. It provides minimum protection measures against bacteria and viruses propagating from on-site sanitation systems. In an Africa context, these pollution sources could include cattle kraals, drinking troughs (feedlot); graveyards (cemetery sites) etc in rural areas. The concept of the safe distance has, for example, been adapted in South Africa in an attempt to deal with the negative impact of pit latrines on groundwater quality. A technical guideline was thus developed by the national Department of Water Affairs and Forestry in South Africa (Xu and Braune, 1995) with "rule of thumb" estimates of the safe distance. Minimum distances of between 10 and $50 \mathrm{~m}$ are prescribed between water point and latrine or other point source of pollution. The guideline identifies three factors that dictate the optimum separation between latrine and water point: the depth to watertable, the composition of the soil and the characteristics of the aquifer. The guideline was followed by practical protocols aimed at field operators (DWAF, 1997 and DWAF, 2003).

In certain areas where hydrogeological conditions are known to water professionals, a set of formulae can be used for estimation of the minimum distance (Xu and Braune, 1995). Actual values of the separation distance to be used for specific sites depend on such parameters as aquifer thickness, porosity, hydraulic gradient, average pumping rate and duration.

Another typical example is a minimum distance of $10 \mathrm{~m}$ between borehole and pit latrine for basement aquifers, as proposed in the DFID (UK) ARGOSS Project (Lawrence et al., 2001). 
The concept of the minimum distance is related to a travel time that would ensure the decay of degradable contaminants like bacteria and viruses. It may also delay and dilute encroachment of non-degradable contaminants such as nitrate but cannot prevent their encroachment in the long-term. An alternative would require a much comprehensive zoning equivalent to the catchment area of the borehole concerned.

In short, the minimum separation, together with proper borehole construction, forms the core of a first tier protection strategy to ensure that potential sources of contaminants, such as inappropriate sanitation and poor borehole construction are dealt with immediately.

\subsubsection{Stepwise procedure from case studies}

The link between sanitation and water source has been demonstrated repeatedly with faecal coli contamination of rural community drinking water supplies. The DFID (UK) ARGOSS Project (Lawrence et al., 2001) highlighted the transport of faecal bacteria in groundwater using case study examples from Uganda and Bangladesh. A key product from this work is a set of guidelines with an accompanying set of rules for determining the optimum distance to separate pit latrine from water source in a range of hydrogeological conditions (see Table 4.5).

There are four steps to the assessment:

1. collect information on the location and design of existing water points and effluent disposal units;

2. assess attenuation potential in the unsaturated zone;

3. assess attenuation potential below the water table;

4. assess attenuation potential due to natural groundwater transport.

The easiest way to demonstrate the methodology is by example from Uganda:

- STEP 1 A village is in low relief weathered basement strata, clayey near surface but otherwise granular down to 20 to $30 \mathrm{~m}$ below which is fractured bedrock. The water table is between 5 and $10 \mathrm{~m}$ below ground level. Long term average annual rainfall is $1000 \mathrm{~mm}$.

- STEP 2 As the water table is shallow the unsaturated zone cannot offer any useful protection above the water table despite the presence of a shallow clay horizon in the upper zone of weathering, because the clay may be fractured or impersistent. Besides the base of the pit latrines may be below the base of the clay unit.

- STEP 3 Shallow dug wells are likely to allow contact with the shallow groundwater just below the water table where contamination is likely to be greatest. In the case of drilled boreholes, well screen needs to be at least $10 \mathrm{~m}$ below the water table to afford protection from nearby pit latrines. If it is less than $10 \mathrm{~m}$ proceed to Step 4.

Table 4.5. Horizontal separation guide (after Laurence et al., 2001).

\begin{tabular}{|c|c|c|c|c|c|}
\hline Rock type & Porosity & Kh: Kv ratio & $\begin{array}{l}\text { Likely } \\
\text { permeability } \\
(\mathrm{m} / \mathrm{d})\end{array}$ & $\begin{array}{l}\text { Is horizontal } \\
\text { separation } \\
\text { feasible? }\end{array}$ & $\begin{array}{l}\text { Separation } \\
\text { needed to reduce } \\
\text { pathogen arrival } \\
\text { at water point (m) }\end{array}$ \\
\hline Silt & $0.1-0.2$ & 10 & $0.01-0.1$ & Yes & Several \\
\hline $\begin{array}{l}\text { Fine silty sand } \\
\text { Weathered }\end{array}$ & $0.1-0.2$ & 10 & $0.1-10$ & Yes & Several \\
\hline basement & $0.05-0.2$ & $0.01-10$ & $0.01-10$ & Yes & Several \\
\hline Medium sand & $0.2-0.3$ & 1 & $10-100$ & Difficult & Tens of hundreds \\
\hline Gravel & $0.2-0.3$ & 1 & $100-1000$ & No & Hundreds \\
\hline Fractured rock & 0.01 & 1 & High & No & Hundreds \\
\hline
\end{tabular}


- STEP 4 The Table suggests a separation between latrine and water point of 'several metres'. Erring on the conservative side a suggested separation of $10 \mathrm{~m}$ will allow for any higher permeable zones that may be present in the weathered zone.

As a practical guide assume the unsaturated zone and the saturated zone provide inadequate protection for water points and go straight to Step 4. Use the table as a guide to obtain the recommended horizontal separation.

The pollution hazards imposed by the point sources would be greatly reduced by application of the minimum distance during water borehole siting stage. Thanks to its simplicity and no need for complicated calculation, the minimum distance concept, as an immediate, basic protection measure, should be applied throughout Africa where no better protection measures are implemented.

If the safe distance is regarded as the first line of defence against contaminants attack, a protection zone would be a comprehensive approach to deal with the encroachment of both degradable and persistent contaminants toward a production well or borehole.

\subsubsection{Zoning approach}

The core of the protection zoning approach is the wellhead protection or borehole protection zoning adopted in many developed countries, which is illustrated by Figure 4.2. Figure 4.2 shows the basic concept of wellhead protection based on delineating the capture zone, or zone of contributing for a specific well (borehole). In this simple concept, the wellhead protection area, or WHPA, is the surface expression of the region contributing water to the well. In the simple porous-media flow system illustrated in Figure 4.2 the WHPA is a symmetrical area extending from just downgradient of the well to an upgradient groundwater divide.

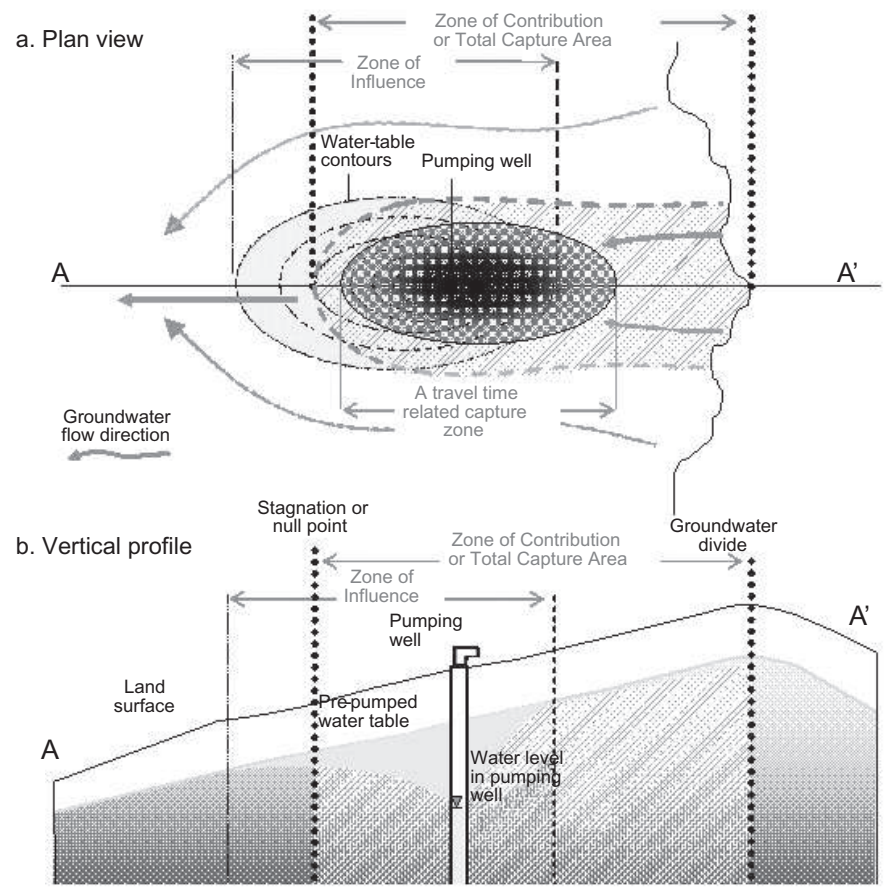

Figure 4.2. A sketch illustrating basic concept of a wellhead protection area with both plan view in (a) and cross section in (b) (after US EPA, 1987). 
The delineation of a wellhead protection zone is the process of determining what land or geographic area should be included in a protection zone program. This area of land is then managed to minimize the potential of groundwater contamination by human activities that occur on the land surface or in the subsurface.

Contamination of groundwater sources has been observed world-wide, and it is becoming self-evident that concentrated human activity will lead to even more groundwater contamination. In general it has been shown that contamination of drinking water occurs where three main components exist:

1. A potential source of contamination,

2. An underlying aquifer, and

3. A pathway for transfer between the two.

This pathway can be either indirectly through the soil, or directly through man-made structures which intersect the water table such as boreholes, trenches and quarries. The size and shape of the borehole protection zone depends upon the hydrogeologic characteristics of the aquifer system, and the design and operational characteristics of the boreholes (or wells) used to pump water from the aquifer system.

Delineation of groundwater source protection zones aims to reduce the effect from these different components, based on the fact that all contaminants do not pose the same risk to the aquifer users, and that the contamination flow path in the aquifer, might not affect users far away or in another part of the aquifer. Commonly, zones or areas are delineated to achieve the following levels of protection (Figure 4.3) (Javandel and Tsang, 1986; Chave et al., 2006; Nel et al., 2009):

- A Wellhead Operational Zone immediately adjacent to the site of the borehole or wellfield to prevent rapid ingress of contaminants or damage to the borehole (also referred to as the 'Accident Prevention Zone').

- An Inner Protection Zone based on the time expected to be needed for a reduction in pathogen presence to an acceptable level (often referred to as the 'Microbial Protection Area').

- An Outer Protection Zone based on the time expected to be needed for dilution and effective attenuation of slowly degrading substances to an acceptable level. A further consideration
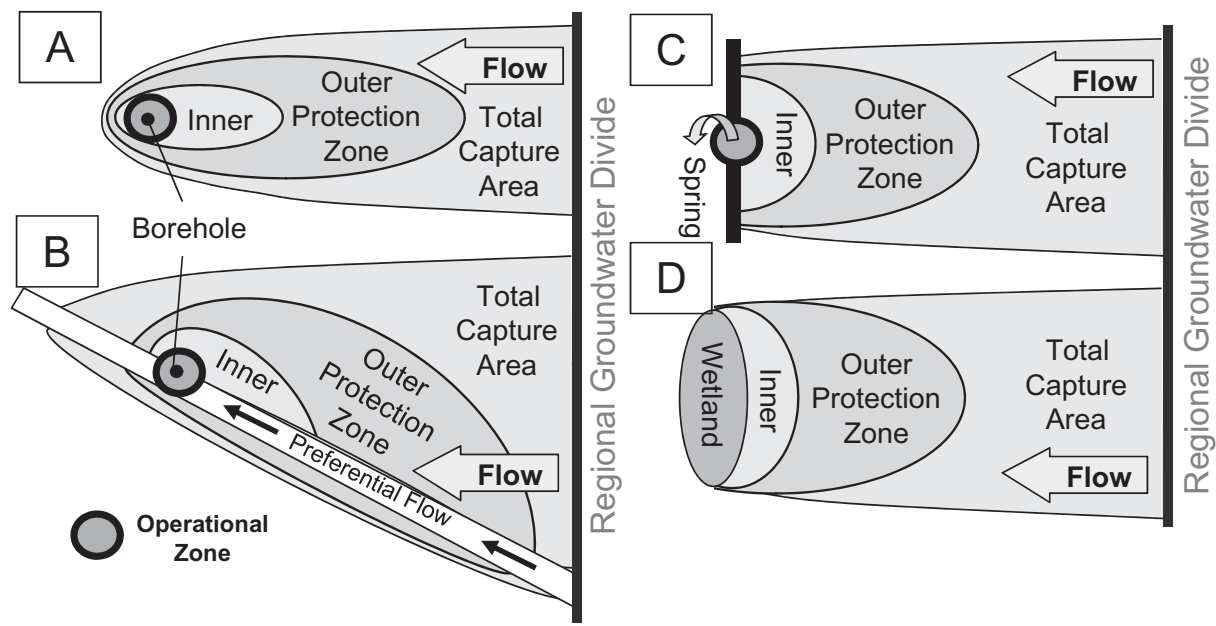

Figure 4.3. A sketch illustrating protection zones under four hypothetical hydrogeological settings. 
in the delineation of this zone is sometimes also the time needed to identify and implement remedial intervention for persistent contaminants.

- A further, much larger zone sometimes covers the total catchment area of a particular abstraction where all water will eventually reach the abstraction point. This is designed to avoid long term degradation of quality.

The number of zones defined to cover these functions varies between countries, usually ranging from 2 to 4 . By placing some form of regulatory control on activities taking place on land which overlies vulnerable aquifers, their impact on the quality (and in some cases quantity) of the abstracted water can be minimised. The concept can be applied to currently utilized groundwater and to unused aquifers, which might be needed at some time in the future. Whatever number of zones are to be implemented, one can not overemphasise the importance of a sanitary seal in the vicinity of a borehole as pointed out in Section 4.2. A typical operational zone where headworks allow drainage of washing water and other spillage away from the wellhead is advisable (Figure 4.4). The zone may also include some water pumping facilities of fixed nature, often built on or attached to headworks including the pump house and some other traditional equipments as illustrated by the Libyan in Figure 19.1 of Chapter 19 of the Part II of this book.

It is important to provide guidance on activities which are either acceptable, unacceptable or need to be controlled in various protection zones. In some countries such lists are very extensive and specific. In others, general guidance is issued. With each protection zone comes land use constraints. These constraints are of increasing strictness moving from the outer protection zone to the wellhead operational zone. Table 4.6 gives a list of typical land use constraints associated with each zone.

The extent of groundwater contamination is often indicated by the distribution and nature of land uses in an area. From this information, the environmental and public health significance of any such contamination can be assessed (NWQMS, 1995; Usher et al., 2004). For example, areas of concentrated manufacturing industries are often associated with contamination of heavy metalsand organic compounds. Areas of intensive horticulture have been related to excessive pesticide and fertilizer contamination. Landfills generate leachate which can result in groundwater contamination from a range of contaminants.

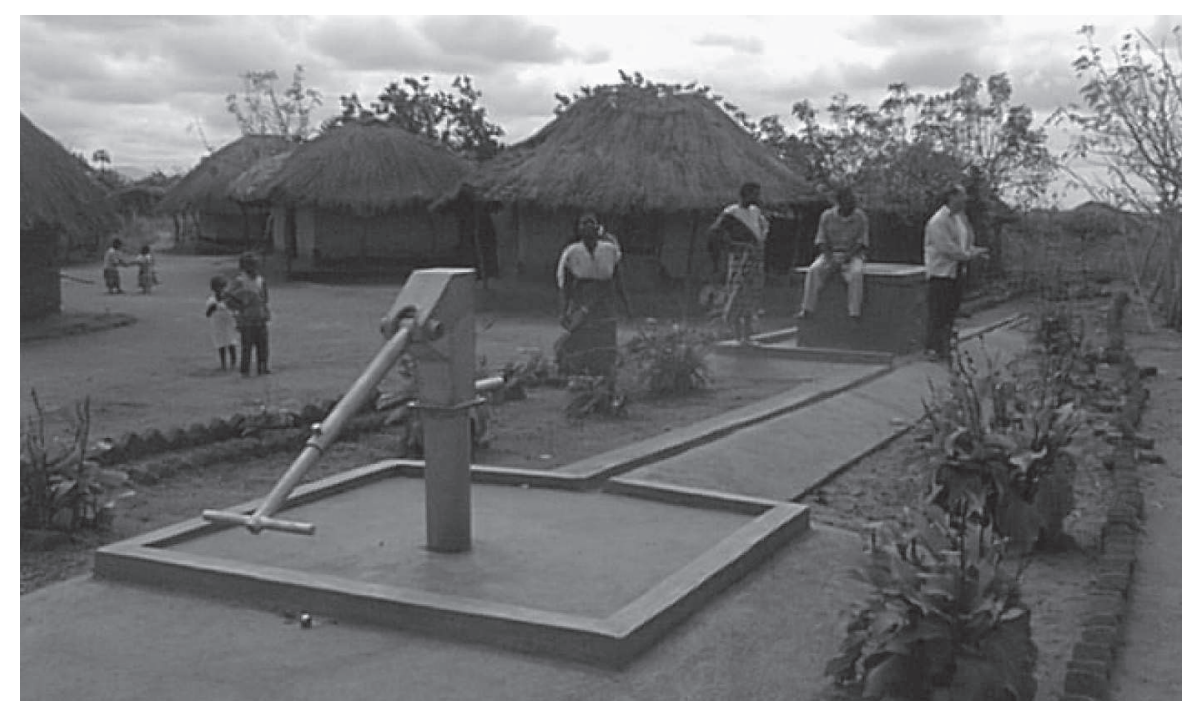

Figure 4.4. A typical wellhead protection layout in Malawi. 
Table 4.6. Land use constraints for protection zones (Jolly and Reynders, 1993; Xu and Braune, 1995; Foster et al., 2002; Nel et al., 2009).

\begin{tabular}{ll}
\hline Zone & Land use constraint \\
\hline Wellhead operational zone & All constraints of inner protection zone and outer protection zone \\
& Agriculture \\
Traffic - both pedestrian and automotive & All constraints of outer protection zone \\
Inner protection zone & Cattle kraals/Feedlots \\
& Sewage sludge \\
Small settlements & Pit latrines \\
Mining \\
Fuel storage \\
Cemeteries \\
Workshops \\
Farm stables and sheds \\
Roads and railways \\
Parking lots \\
Hospitals \\
Wastewater and sewage treatment facilities \\
Solid waste sites \\
Mass livestock \\
Airports and military facilities \\
Oil refineries \\
Chemical plants and nuclear reactors \\
Large informal settlements using pit latrines \\
Storage of hazardous substances underground \\
\end{tabular}

\subsubsection{Protection approach in fractured rock aquifers}

Fractured rock aquifers are common on the African continent, and provide water supplies for hundreds of millions of people. For the purposes of this paper, a fracture is defined as any hydraulically conductive discontinuity or break in a rock mass, without regard to origin. Although most geologic materials contain fractures at some scale, fractured rock aquifers are water-bearing formations in which most groundwater transport is through a fracture network rather than through a porous matrix. Almost any rock type can contain fractures, and the lithologies that generally form fractured aquifers include crystalline rocks (granite, basalt), metamorphic rocks (schist, gneiss, quartzite), and fine-grained carbonate rocks (limestone, dolomite). In Africa and elsewhere the igneous and metamorphic rocks commonly occurring near the land surface are often called basement rocks. Such rocks, composed of interlocking mineral grains, have very low matrix or primary porosity. Fractures in these rocks form through weathering processes and structural stresses, and the resulting fracture porosity is called secondary porosity. Limestone and dolomite are sedimentary rocks that also can have significant secondary porosity. Groundwater movement through these rocks can widen the fractures by chemical solution to produce karst features (conduits, caves, and sinkholes). Fractured rock aquifers therefore span a continuum from the sparse, small-aperture fractures often found in crystalline rocks such as granite to large bedding-plane fractures and conduit features found in carbonate rocks such as limestone.

Protection of fractured-rock aquifers requires recognition of the hydraulic and geologic characteristics that make these settings so vulnerable to contamination. Such characteristics 
can include flow through interconnected preferential pathways (fractures, karst conduits, macropores), high flow velocities, low effective porosity, rapid and large changes in hydraulic head or water levels, rapid recharge, and potentially little attenuation of contaminants. Fractured aquifers are generally more vulnerable to contamination than are porous granular aquifers composed of sandstone or sand and gravel. Groundwater movement through fractured aquifers can be very rapid - tens to hundreds of meters per day compared to only a few millimeters or centimeters per day in many granular aquifers. In addition, fractured rocks usually offer less opportunity for natural filtration or degradation of contaminants than do porous rocks. Consequently, many fractured aquifers can transport contaminants rapidly for long distances with little attenuation of contaminants.

The concept of groundwater protection zoning covers a spectrum of activities from general protection of large regions to delineation and protection of detailed contributing areas for specific wells or springs. In all cases, protection is a two-step process, including technical delineation of critical areas followed by the application of zoning or land-use controls to protect those areas. Most groundwater protection plans must strike a balance between the availability of technical resources and data and the need to accomplish meaningful protection in the face of uncertainty and complexity. The goals of groundwater protection must also be clear, and can differentiate between regional groundwater protection, protection of specific wells and springs, and protection of "environmental" groundwater needs such as stream baseflow and maintenance of wetlands.

The key to aquifer protection is a basic understanding of local hydrogeology. Even in complex geologic environments, the basic principles of groundwater flow still hold. Water moves from higher to lower hydraulic head through the most permeable parts of the geologic framework. Recharge depends on the characteristics of the uppermost geologic and soil layers and on the distribution of precipitation and runoff. Surface water features (lakes, rivers, oceans) and geologic structures (faults, unconformities, intrusions) form important boundary conditions. All protection methods, from simple calculations to sophisticated models, must begin with these basic conceptual models.

\subsubsection{Index methods for regional groundwater protection}

Most regional groundwater protection plans begin with development of vulnerability or susceptibility maps based on an index ranking method (Figure 4.5). A variety of such ranking methods have been developed, and Gogu and Dassargues (2000) provide a good summary of these techniques. Vulnerability mapping methods usually include overlay mapping of various geologic characteristics controlling groundwater vulnerability, such as depth to bedrock, depth to the water table, aquifer type, soil characteristics, and other factors. Figure 4.5 shows an example of an index mapping techniques applied to a fractured dolomite aquifer in a rural area of Wisconsin in the United States. In this area, thin soils overlie the fractured dolomite. These authors considered soil thickness to be the main control on vulnerability of the aquifer in this area, and the resulting map rates areas of thin soil (less than 1.5 meters thick) as most susceptible to contamination. Recently Vias and others (2006) proposed a vulnerability ranking scheme called the COP method (Concentration of flow, Overlying layers, Precipitation) and applied it to pilot sites in carbonate aquifers in southern Spain. Once vulnerability maps are produced local managers might then enact land-use controls or restrictions on the distribution of land-use activities having the potential to contaminate groundwater.

\subsubsection{Delineation of the wellhead protection}

Wellhead protection is essentially the two-step practice of, first, delineating the land surface area contributing water to a specific well (borehole) or wellfield (borefield) and, second, enacting zoning to minimize potentially polluting activities within this area. Application of wellhead protection in the fractured rock aquifers remains a challenge as practical approaches for groundwater and wellhead protection in such environments range from simple (establishing a fixed-radius protection zone around a well with low confidence) to complex (development of 

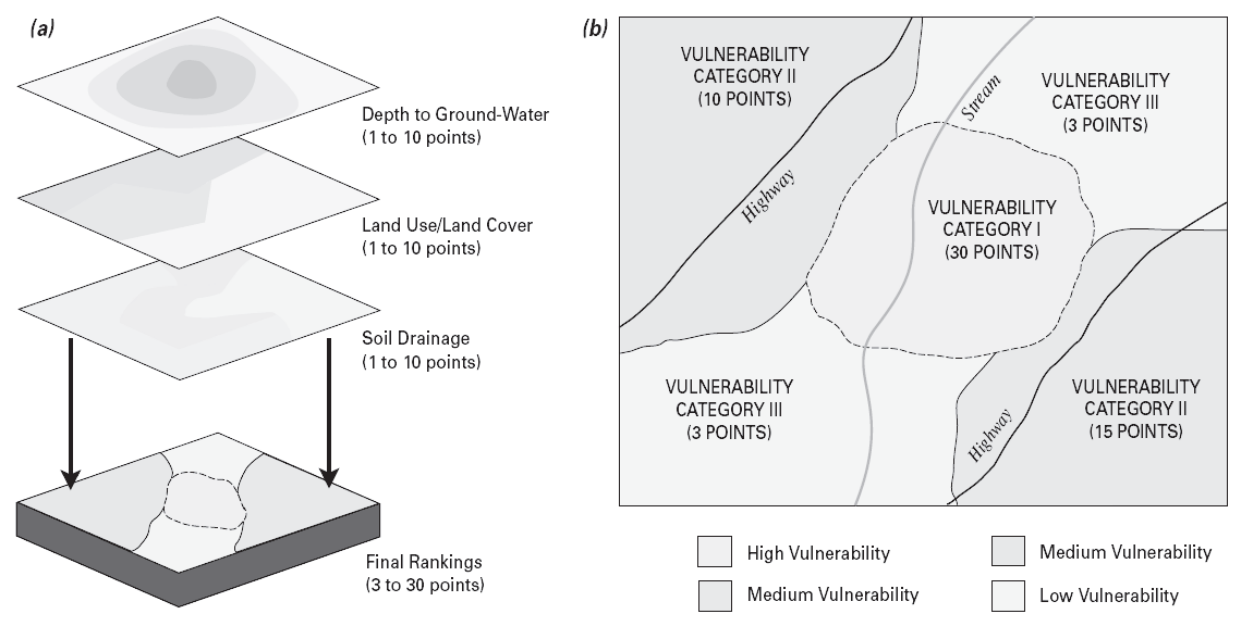

Figure 4.5. Basic concept of an index method for mapping relative vulnerability to contamination. From Focazio et al. (2002).

a groundwater flow model for a large region with high confidence) and usually depend on the resources and data available. In 1991 the US Environmental Protection Agency published a manual for delineating wellhead protection areas in fractured rocks (USEPA, 1991). The basic concepts of wellhead protection have changed little since that time, although methodologies have improved due to recent advances in field instrumentation and computer techniques.

Many wellhead protection studies are based on analytical or numerical model simulations of groundwater flow to wells. Numerical groundwater flow models, such as the USGS MODFLOW code (McDonald and Harbaugh, 1988) are based on porous-media assumptions. Even so, such models can provide reasonable results in some densely fractured rock settings if used judiciously and if the fractured rock characteristics are considered as part of the conceptual model and numerical model construction. For example, Rayne and others (2001) applied a MODFLOW model to delineate contributing areas for municipal wells finished in fractured dolomite at Sturgeon Bay, Wisconsin. They incorporated near-horizontal beddingplane fracture zones as discrete layers in a three-dimensional model, and calibrated the model to local water levels and groundwater discharges. The model-delineated contributing areas were nearly $10 \mathrm{~km}$ in length, and travel times from recharge to the wells were less than two years (Figure 4.6).

In sparsely-fractured aquifers, the contributing area for a well can be very complex, and porous media models may not be appropriate. Figure 4.7 (based on Bradbury and Muldoon, 1994) compares pathlines and time-related contributing areas for a well in a uniform porous medium (top) and a well in a sparsely fractured medium (bottom). Both wells are pumping steadily at equal rates in a regional flow field in which groundwater moves from left to right in each diagram. The oval-shaped WHPA in the upper diagram is typical of well capture in uniform porous media. The irregular WHPA in the lower diagram shows how the fracture pattern controls flow to the well. This hypothetical diagram, based on a numerical model, illustrates the potential error in using porous-media methods for delineating capture zones in sparsely fractured aquifers. Worthington and others (2002) provide a real-world example of this problem from a fractured dolomite site at Walkerton, Ontario, where several people died following contamination of a community well. In this example a porous-media computer simulation predicted a 720 hour travel time to a pumping well, while tracer tests showed that actual flow times through bedding plane fractures ranged from only five to 26 hours. 


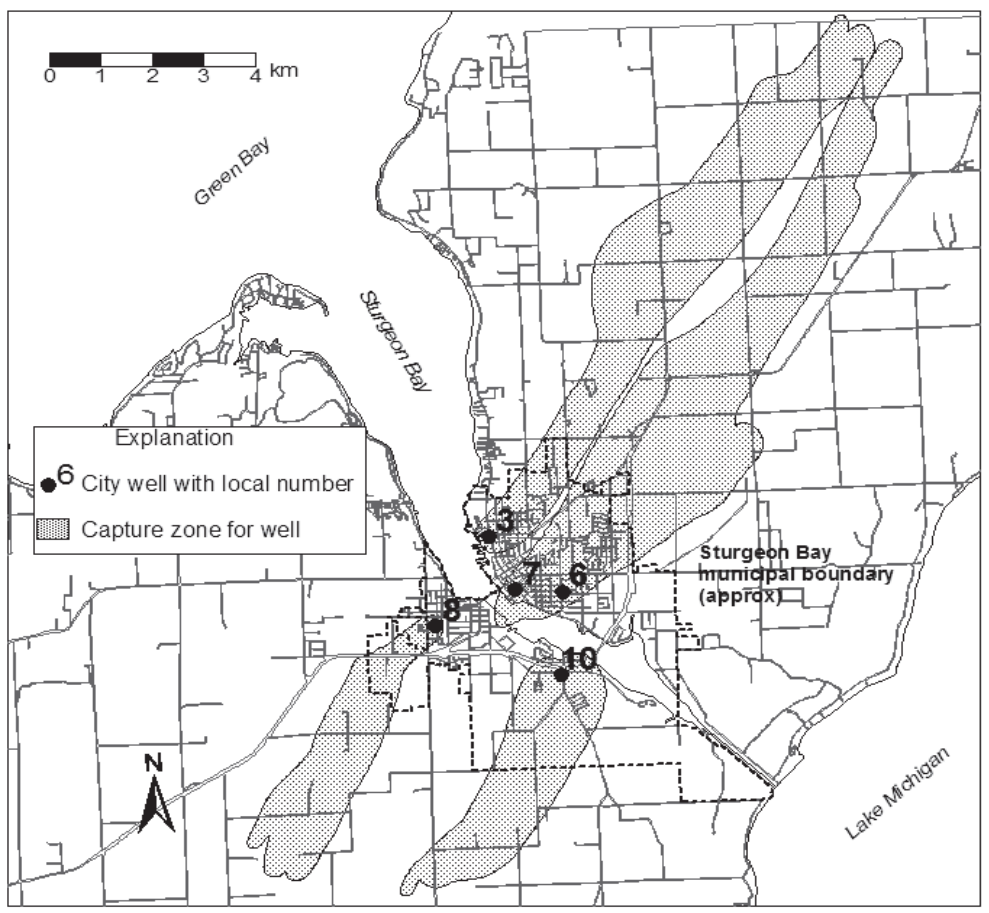

Figure 4.6. Capture zones delineated using a groundwater flow model in a fractured dolomite aquifer, Sturgeon Bay, Wisconsin, USA. Travel times from the termination of the capture zones to the wells are approximately two years. After Rayne et al., 2001.

Bradbury and Muldoon (1994) and the Minnesota Department of Health (2005) discuss criteria for determining when fractured aquifers can be treated as porous media.

In regions or structural complexity or suspected conduit flow, water level contours can be poor predictors of groundwater flow direction. In such areas, investigators often apply delineation techniques based on structural analyses or utilize groundwater tracers. For example, Ginsberg and Palmer (2002) developed guidelines for delineation of contributing areas in steeply dipping limestone aquifers in the eastern United States, where structural dip exerts a major control on groundwater flow direction. Spangler (2002) demonstrated that dye tracing studies can be useful for delineating contributing areas for springs and wells in a karst terrain in Utah, and showed that porous media approaches can underestimate the size of contributing areas in these settings.

Given the complexities and data requirements for detailed delineations of capture zones for wells in fractured-rock settings, most practitioners use a step-by-step approach, moving from simple mapping techniques to (where appropriate) more complex numerical models (USEPA, 1991). The Minnesota (USA) Department of Health (2005) has developed a manual of suggested procedures for delineating contributing areas in fractured-rock and karst settings. Many of these methods begin with a calculated fixed radius approach but then extend the area to natural hydrogeologic boundaries along known fracture or fault traces (Figure 4.7).

Assessments of aquifer vulnerability should also include biological, geochemical, isotopic, and temperature data (USEPA, 1991). Such information is particularly valuable in fractured-rock settings because it offers a separate line of evidence from often-uncertain 

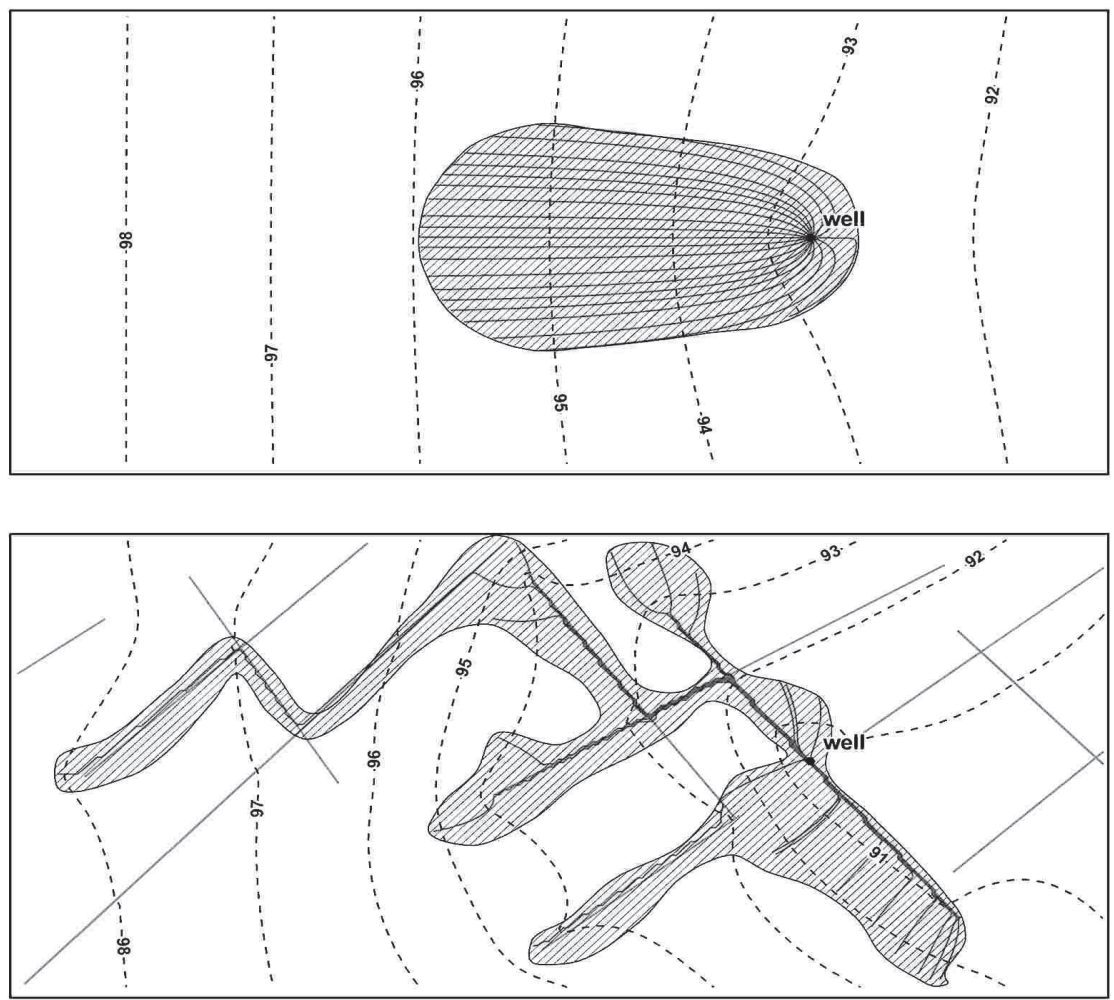

Figure 4.7. Comparison of a contributing area in a uniform porous medium (top) with a contributing area in a sparsely fractured network (bottom). In both diagrams the hatched areas represent the contributing area for a well pumping at steady state in a uniform flow field. Regional groundwater from is from left to right. Time-related particle paths were generated using a numerical flow model. Dashed lines represent equipotentials. Grey lines in the lower diagram represent connected fractures.

hydraulic calculations. For example, the presence of detectable tritium (>1 T.U.) in a well is important evidence that the local groundwater is relatively "young" and vulnerable to contaminants originating at the land surface. Other geochemical constituents (e.g. nitrate, chloride) are inexpensive to sample and analyze and can also indicate recent inputs from the land surface. Isotopes of oxygen and hydrogen can also help discriminate recharge sources. Groundwater temperature changes often correlate with recharge events. And knowledge of biological contaminants (E. Coli, other bacteria, viruses) is essential for protection of public health and for design of water treatment facilities.

\subsubsection{Summary}

The most important considerations for protection zoning in fractured rock environments are, first, a clear understanding of the purpose and scale of the desired protection and second, a clear and accurate conceptual model of the local groundwater system. Regional contamination vulnerability or susceptibility maps developed using index methods are relatively inexpensive to construct and can be the basis for protection zoning that limits contamination sources in the most vulnerable areas. In fractured rock settings these schemes usually give high weight to bedrock depth and soil characteristics as controls on groundwater contamination, with areas of thin or very permeable soil being ranked as extremely 
vulnerable. Protection of specific wells requires knowledge of the hydrogeology of the region around the well and delineation of the area contributing groundwater to the well. Where rocks are highly fractured the flow to wells can often be approximated by porousmedia models, the resulting capture zones are similar to those delineated for porous media. However, wells drawing water from sparsely fractured rocks can have irregular and complex contributing areas, and porous-media approaches and models will not be adequate and in fact can be very misleading. For these situations a conservative approach is often to extend the protected area in the directions of known or suspected conductive features. If resources are available, field studies, including tracer experiments can be used to test connections and determine flow paths to the well. Other geochemical indicators, such as temperature, basic chemical parameters, and isotopes, can be used to help verify the delineated areas.

\subsubsection{Spring and shallow well protection}

Springs and shallow wells are probably still the most common way of water supply to rural communities and even informal urban areas in Africa. The appropriate protection of these already available sources should be one of the highest priorities of any water supply and sanitation programme.

Spring protection is important aspect in modern hydrogeology. As pointed out by Pochon et al. (2008), various techniques including tracer experiment and vulnerability mapping have been applied to groundwater protection zone delineation in several fractured aquifer case studies but criteria for choosing one technique over another for protection zoning purpose are not readily available. Four major types of aquifers in Africa have been introduced previously. These aquifers and their combinations in places allow for a variety of spring occurrences. The most typical and generally observed springs include those located in a topographic depression, along a formation contact, major fault, joints, fracture zone and in the vicinity of Karst cavities as illustrated in Figure 4.8.

Use of springs in Africa has a long history (Xu and Usher, 2006). Community participation plays a crucial role in the sustainable use of this local resource. Mwami (1995) relates a story of

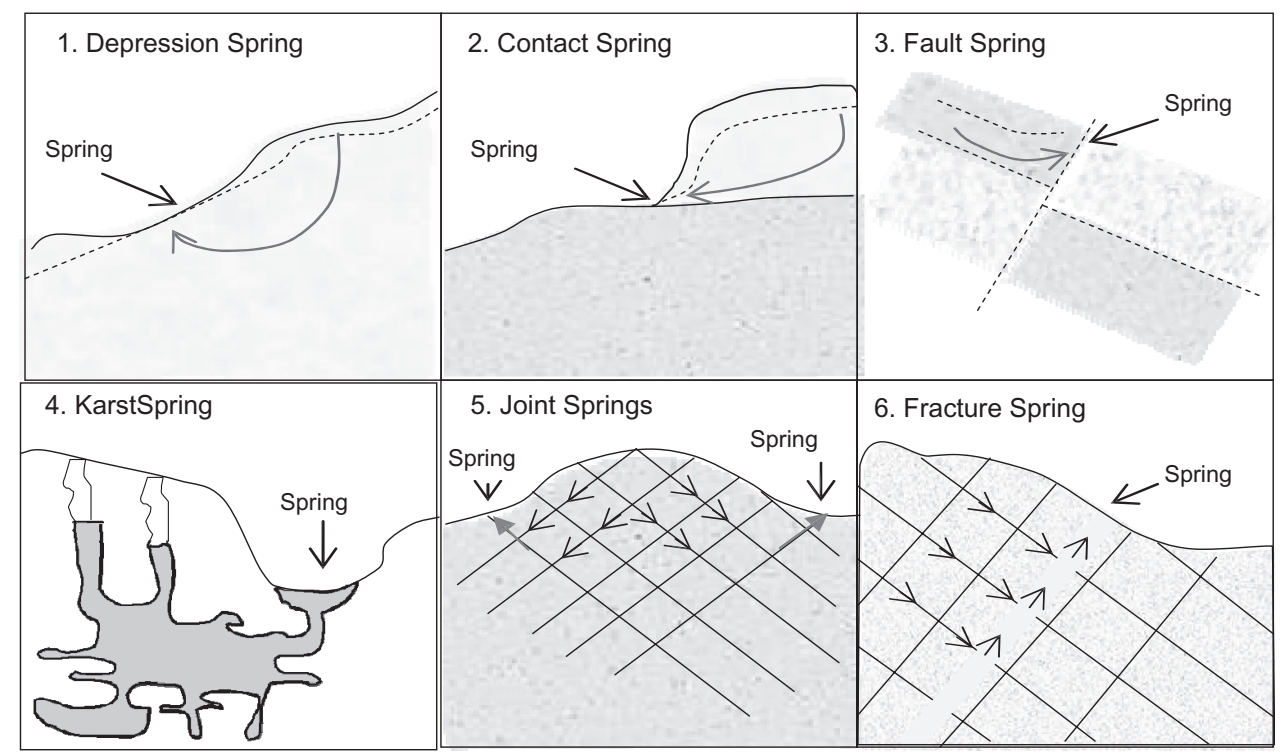

Figure 4.8. Types of springs often observed in field (modified from Harvey, 2004). 
successful spring protection through church-led community participation in Rukungiri in South Western Uganda. As the church there is a very strong indigenous organization, the church leaders are highly respected and their words are taken serious. As a result of the project, a total of 950 springs were protected in the area, serving 56,000 people and providing a $14 \%$ coverage.

To illustrate concept of spring protection, Figure 4.9 is used, in which spring protection requires a spring box with a discharge pipe outlet that can be piped to the point of use. The area between the spring and the spring box is backfilled with appropriate material—gravel to act as a filter medium, capped by a thin clay layer and overlain by sand and topsoil grassed over above. The sides of the infill should be contained within a wall of impermeable material such as clay. The filter medium should reach the upper part of the spring flow horizon under wet weather conditions, and the infill area fenced off. The use of a spring box here also facilitates chlorination of the spring water should this be required. For more detail information on designs, the reader may be referred to Howard et al. (2000).

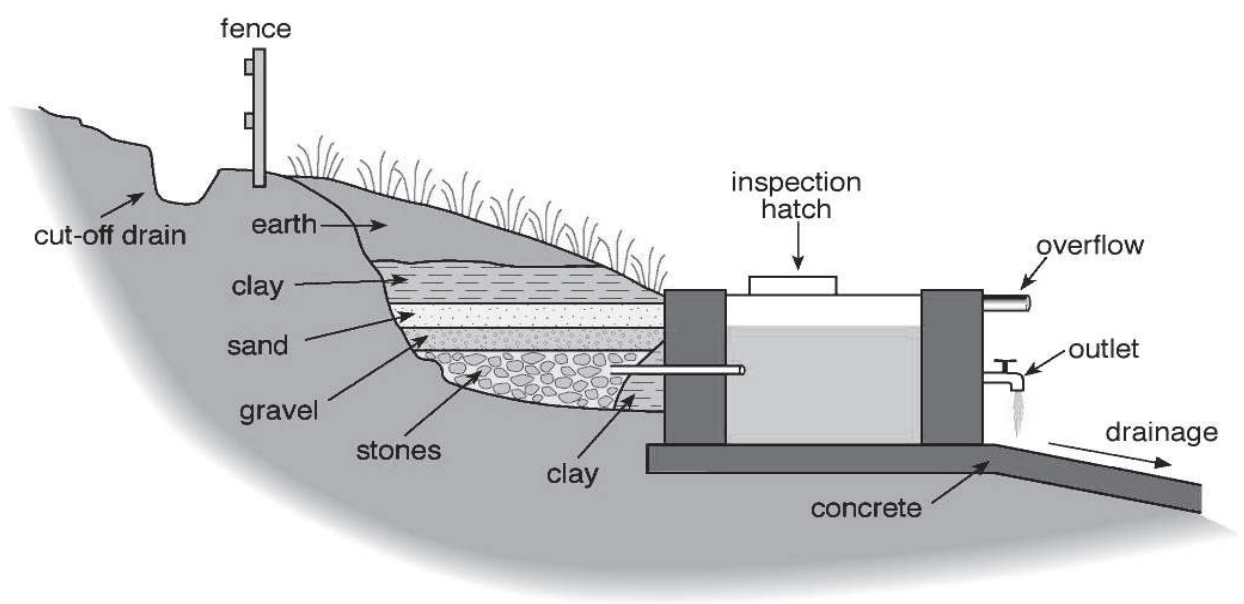

Figure 4.9. Schematic spring protection cross-section (MacDonald et al., 2005).

Table 4.7. Sanitary protection measures (after Lawrence et al., 2001).

\begin{tabular}{lll}
\hline Source & Sanitary measures & Details \\
\hline Spring & $\begin{array}{c}\text { Local protection works to prevent } \\
\text { contamination }\end{array}$ & $\begin{array}{l}\text { Spring eye protected with clay layer and undamaged } \\
\text { Works kept in good order }\end{array}$ \\
& Surrounding area managed & Spring eye area fenced off \\
& & Diversion ditches to take run off away \\
& & Adequate drainage of waste water away from the site \\
& & No ponding in vicinity \\
Dug well & Wellhead protected to prevent & Concrete apron is at least 1.5 m diameter \\
& source contamination & No cracks in apron \\
& & No ponding of water on the apron \\
& & Sound join between apron and borehole casing \\
& & Apron floor slopes away from borehole \\
& Handpump or windlass used for raising water \\
& Surrounding area managed & Area fenced off \\
& Diversion ditches to take run off away \\
& Adequate drainage of waste water away from the site \\
& No ponding in vicinity \\
\hline
\end{tabular}


Dug wells also require protection including a fence to prevent access by animals. The well lining should be impermeable within the top 1 to $2 \mathrm{~m}$ of the well and extend at least $0.3 \mathrm{~m}$ above ground level. Concrete rings are ideal for this purpose, with cement poured behind them to form an impermeable seal around the top of the well. If the well is already lined with brick or other material then an annulus can be dug down to a depth of $1 \mathrm{~m}$ and infilled with cement. An impermeable wall can then be built around the well to a height of $0.3 \mathrm{~m}$ which is founded on the cement seal.

In principle sanitary protection at headworks of groundwater supplies should inhibit contamination of the source by preventing pathways to develop that link the ground surface to the water table. A set of simple measures to protect sources is summarised in the Table 4.7.

If the spring, borehole or well is situated on sloping land then a diversion ditch dug above it will protect it from overland flow. Any abandoned wells or boreholes should either be infilled or properly capped.

\subsection{DROUGHT PROOFING}

\subsubsection{Basic concepts}

The concept of drought has been extensively researched, particularly from meteorological, sociological and agricultural perspectives. However, drought definitions are not consistent. The lack of universally accepted definitions and the inherent difficulties associated with separating causes from impacts creates confusion when describing drought (Calow et al., 1997).

A meteorological drought occurs when rainfall is abnormally low, i.e. less than a critical precipitation. A hydrological drought results when water supply falls below the minimum required for 'normal' functions, reflecting a deficit in the water balance. Similarly, in broad terms, drought also occurs when there is a deficit in water supply, due to insufficient rainfall and surface and sub-surface runoff and storage, so that demand cannot be met.

Groundwater drought is the phase during which groundwater levels are depleted by insufficient recharge so that the resource is no longer able to sustain normal demand and withdrawal. Theoretically, only when the meteorological drought is advanced does the groundwater drought occur, and only after the meteorological drought is over and recharge to aquifers occurs causing groundwater levels to rise will the groundwater drought end. Concurrent with the onset of groundwater drought, sources begin to fail. Indicators include failure of poorly maintained and overstressed pumps and additional pressure on the declining number of operating water points that a community can rely on. In practice it is rarely the total failure of the resource that leads a community to critical water shortage but their reduced access to the resource. Meteorological drought causes surface water sources to dry up, many of which may be ephemeral, although flow within sand river beds may still occur. A traditional drought coping strategy is the excavation of dug-outs in the sand rivers to sustain both community and its animals. A longer term water storage strategy involves the construction of sand river dams.

Past responses to drought have been reactive, e.g. the mobilisation of emergency borehole drilling, trucking water supplies, community feeding programmes and provision of animal feed (Clay et al., 1995). Responses need to take into account the sustainable management of all natural resources so that appropriate use of the available groundwater can be achieved to mitigate the impact of drought when surface waters are in deficit (Calow et al., 2009). This requires the development of appropriate groundwater management strategies for drought prone areas to mitigate the impact of drought on community life as well as associated natural systems and resources.

There are numerous coping strategies that can be invoked, each designed to lessen the impact of drought on community livelihood and wellbeing. Drought coping strategies include:

Sand-river dams: An impermeable wall is placed across a suitably constricted section of a sand river behind which sediment and water can accumulate. The water in the sand below 
2 metres depth cannot evaporate and is stored in the sand following periods of flood. The filling of the reservoir with sand behind a newly constructed dam takes place in about 5 to 7 years. Mixed coarse to fine-grained sands and gravels are deposited by the initial flood, sediments tending to fine upward as the flood subsides (Hussey, 2007). With subsequent floods the finer top layer is eroded away by the new flood and more sand is deposited, so increasing the thickness of the mixed coarse to fine grained sands and gravels.

When the water level in the riverbed decreases following a period of flood, the groundwater in the banks may slowly discharge to the riverbed. This process can occur in ephemeral rivers. As the thickness of sand in the storage dam increases so the water storage potential in the sand also increases. By raising the level of the sand in the river, the 'base level' of the groundwater flow may also be raised, potentially increasing the amount of water that is stored in the banks and the volume that can be withdrawn. The amount of water stored behind a sand storage dam is thus higher than just the amount of water stored in the sand behind the dam. Typical yields from a sand dam are between 2 and $10 \mathrm{~m}^{3} /$ day throughout a normal dry season. This is additional water which a community can use to its best advantage with virtually no impact on other local demands for water.

Shallow wells in bank deposits adjacent to sand river dams can draw on the enhanced storage created by the dam. This can enable facilities such as community gardens. Whereas these shallow wells draw on the enhanced storage of the dam, a well or shallow borehole placed below the dam will draw on leakage from it, either under the dam foot or in fractures and cracks in the underlying bedrock. These wells or boreholes actually increase the ultimate yield of the dam. The most important conditions for the application of sand storage dams are:

- Coarse sand and gravels material in the riverbed more than 2 metres thick.

- Poorly permeable layer underneath the proposed dam site.

- Short periods of high intensity storm-event rainfall, that can rework remove silt from the deposits within the sand dam aquifer.

- Organised community to participate in constructing and maintaining the dam and the sustainable use of water abstracted.

Monitoring pump status and repair: This is an essential exercise that is lacking in many countries in Africa and hinders reliable supply. Villagers can be empowered to report the status of their water points in order that repairs be undertaken. However, no programme of systematic maintenance can be effective without monitoring and the two need to be performed together to be effective. Very few if any communities normally monitor water levels or abstraction rates on a systematic basis.

Reserve deep boreholes for emergency use: Deep drilling at hydrogeologically favoured sites between a group of villages has been advocated by some as a valuable form of drought proofing. The boreholes would be opened and equipped only at times of water stress in the surrounding villages. Although it is focussed partly on livelihood, it in fact provides only domestic water as villagers cannot transport other than domestic requirements. Consequently this form of intervention is not cost effective. Reserve and isolated deep boreholes are also open to abuse as enterprising farmers will be tempted to tap the potential of the borehole during normal times in order to provide water for stock watering or irrigation of fodder crops.

Well deepening: Programmes of well deepening and of drilling through the bottom of hand dug wells to increase access to deeper groundwater are only successful if good quality groundwater is available at depth. Although relatively deep aquifers are sourced for domestic wellfield supply in some countries, the aquifers elsewhere - such as the weathered Basementare, for the most part, relatively shallow and their transmissivity declines rapidly with depth.

Rehabilitation: Repair of broken infrastructure is a valuable form of drought proofing. Effort spent in redressing the operational status of a water point is money well spent and by far a cheaper option than attempting emergency intervention should drought again arise. Rehabilitation of the water points in a village community allows that village to maintain its livelihoods at times of water stress. It is important to retain accessible technology, i.e. repairs 
to hand pumps rather than installation of motorised pumps for which there is unlikely to be any fuel. There also needs to be some form of borehole failure assessment as breakdown may be due to aquifer resource depletion.

Community empowered monitoring: A simple and cost effective coping strategy is empowerment of a community. One effective means is to equip a community with the means of monitoring its own infrastructure. A length of string and weight is enough to measure the depth to water in its village wells - best done at dawn each day before the daily drawdown on the aquifer commences. This may not be possible in the majority of boreholes where there is no access to the water table from the ground surface. Measurement of the number of buckets drawn from a well provides a useful indicator of demand and how demand might change in response to changed conditions. Other indicators that can easily be self measured include number of cattle owned within a village, or quantity of vegetables taken from a community garden. These data combined with health indicators such as the number of patients dealt with by the local clinic can provide valuable insight into the overall status of the village not just in terms of its food security but its wellbeing and its water security status.

Community empowered water point maintenance: Empowerment of a village to self maintain its infrastructure can take a variety of forms including the appointment of a water committee which might chose to elect a keeper of the community well or wells. A small tariff might be applied against income within the village which allows the purchase of spare parts for pumps and pays the local mechanic to undertake repair as required. It can also be used to maintain the integrity of the sanitary slab at well/borehole top to minimise pollution. Such structures are widespread throughout many of the semi-arid savanah lands of Africa.

Small scale irrigation: Small scale irrigation of community gardens has been widely advocated as a means of improving livelihood and in making rural communities more resistant to external shocks. A variety of water sources may be available, for example, a spring used for stock watering and dirty water left to soak away downstream might be captured for use both for stock and garden watering. Clearly the garden has to be fenced in order to keep out animals, and some reticulation may be required to bring water to the garden. In addition a community garden needs to be accessible to the community and needs to be in close proximity to the village and under its guard from possible predators.

Rainwater harvesting: Tin roofs with gutters are suitable for rainwater collection. Downspouts draining to containers can collect a significant quantity of water to maintain a garden in the dry season at, for example, a district clinic or school.

\subsubsection{Types of drought}

There are several types of drought defined in the literature. Agricultural drought exists when soil moisture is depleted to the wilt point such that rain-fed crop and pasture yields are reduced and some susceptible crops die before cropping. A meteorological drought, the cause of agricultural drought, is the persistent failure of the rains. Typically one failed rain season causes failure of the crops, the second consecutive failed rain season causes death of animals, and subsequent to this the death of people. However, in the meantime livelihood has suffered and intervention is required. Various early warning systems are in place to predict meteorological drought in order that ameliorating strategies can be put in place. However, these concentrate more on food security than they do on water security and are in any case generally inadequate.

Drought is a relative concept, defined in terms of a deviation from the norm. In semi-arid lands it is critical to wellbeing whereas in European terms it may mean restriction in water use such as hose pipe bans with little real impact either on community and wealth. However, drought in Africa is potentially life threatening and should not be considered as unusual, it is a recurring event that must be catered for within both national and regional strategies. 
Table 4.8. Livelihood approach.

\begin{tabular}{|c|c|c|}
\hline Livelihood & Food first solution & Sustainable livelihood approach \\
\hline Objective & Access to food & $\begin{array}{l}\text { Secure and sustainable livelihood maximising access } \\
\text { to all assets to support production, income and } \\
\text { production }\end{array}$ \\
\hline Priorities & Food first & $\begin{array}{l}\text { Livelihood needs including water for income } \\
\text { generation }\end{array}$ \\
\hline Entitlements & $\begin{array}{l}\text { Narrow entitlement } \\
\text { base }\end{array}$ & $\begin{array}{l}\text { Broad base including access to common pooled } \\
\text { resources such as water }\end{array}$ \\
\hline Vulnerability & Lack of food & $\begin{array}{l}\text { Insecurity: exposure to shocks and stress including } \\
\text { lack of ready access to water }\end{array}$ \\
\hline Vulnerable groups & $\begin{array}{l}\text { Based on social and } \\
\text { medical criteria }\end{array}$ & $\begin{array}{l}\text { Based on wider set of livelihood security indicators } \\
\text { but including water availability and use }\end{array}$ \\
\hline Coping strategies & $\begin{array}{l}\text { Designed to maximise } \\
\text { access to food }\end{array}$ & $\begin{array}{l}\text { Specifically designed to preserve livelihoods and } \\
\text { include trade-offs between expenditure on } \\
\text { accessing water and preserving consumption, } \\
\text { production and income }\end{array}$ \\
\hline $\begin{array}{l}\text { Measurement and } \\
\text { monitoring }\end{array}$ & $\begin{array}{l}\text { Narrow: food availability } \\
\text { and access }\end{array}$ & $\begin{array}{l}\text { Broad: livelihood security and sustainability, } \\
\text { including water security indicators. Emphasis } \\
\text { must be on local assessment }\end{array}$ \\
\hline $\begin{array}{l}\text { Supporting } \\
\text { interventions }\end{array}$ & $\begin{array}{l}\text { Food aid, food-for-work, } \\
\text { food stamps etc }\end{array}$ & $\begin{array}{l}\text { To protect livelihoods and assets, i.e. co-ordinated } \\
\text { food and water interventions }\end{array}$ \\
\hline
\end{tabular}

But in defining drought, sufficient data must be gathered to help describe the normal conditions of the system and the critical conditions at which normality can no longer be sustained without external intervention. Internal intervention can include subsidised purchase of livestock to remove them from the arid pastures, promotion of drought resistant but nevertheless rain-fed crops, provision of free fertilizer, food aid and local medical assistance. External intervention is that which Government can no longer cope with and which requires emergency intervention by global NGOs, much of which is short term assistance, e.g. emergency and ill-defined drilling programmes, which do little to drought proof an area in the longer term.

Other terms used in water scarcity are:

- Water shortage-occurs when available water does not meet minimum needs,

- Water scarcity - relates water demand to availability and use,

- Water stress - caused by scarcity can result in conflict due to crop failure,

- Water security-reliable and secure access to water.

\subsubsection{Livelihood approach}

Livelihood is one of great concerns associated with drought strikes. The relationship between livelihood, food first solution and sustainable livelihood approach is outlined in Table 4.8.

\subsection{ON-SITE SANITATION AND GROUNDWATER}

There is an urgent need for a joint discussion of on-site sanitation and local groundwater supply. Both have the ultimate objective of enhancing community health. The World Health Organisation (WHO) provides one definition of sanitation as "the science and practice of effecting healthful and hygienic conditions", whilst in its 'Guidelines for Drinkingwater Quality' it equally stresses health: drinking-water quality is an issue of concern for 
human health in developed and developing countries world-wide. The risks arise from infectious agents, toxic chemicals and radiological hazards. Experience highlights the value of preventative management approaches spanning from water resource to consumer" (quoted from McCarthy, 2008).

Throughout Africa, groundwater is by far the most important source for drinking and other domestic needs. And at the same time, across the continent, it is inadequate sanitation that presents the greatest risk to the quality of groundwater supplies. This section will therefore briefly look at various on-site sanitation practices, not comprehensively and in terms of their overall pros and cons, but only in terms of their impact on local groundwater supplies (Figure 4.10 and Table 4.9). This is not just a technical issue, but has to become part of the choice each community must make towards the most feasible and convenient option to provide necessary health protection.

The further discussion of on-site sanitation practice is taken largely from WHO (1992) and IRC (2004). Sanitation refers to excreta and waste water management as well as runoff water and solid and industrial waste. There are different technologies available to deal with sanitation and two main types can be distinguished:

- off-site sanitation which is appropriate for large scale exploitation, based on technical and economic feasibility studies (sewer networks, runoff water drains, etc);

- and on-site sanitation.

On-site sanitation can be defined as the whole of actions related to the treatment and disposal of domestic waste water that cannot be carried away by an off-site sanitation system because of low density of population. This could mean:

- individual on-site sanitation, when a house (plot) makes use of the soil as a treatment medium (example of soak-away, latrines, etc);

- grouped on-site sanitation (or semi off-site sanitation), when many individual houses are linked to a network leading to a treatment system, or small communities: grouped

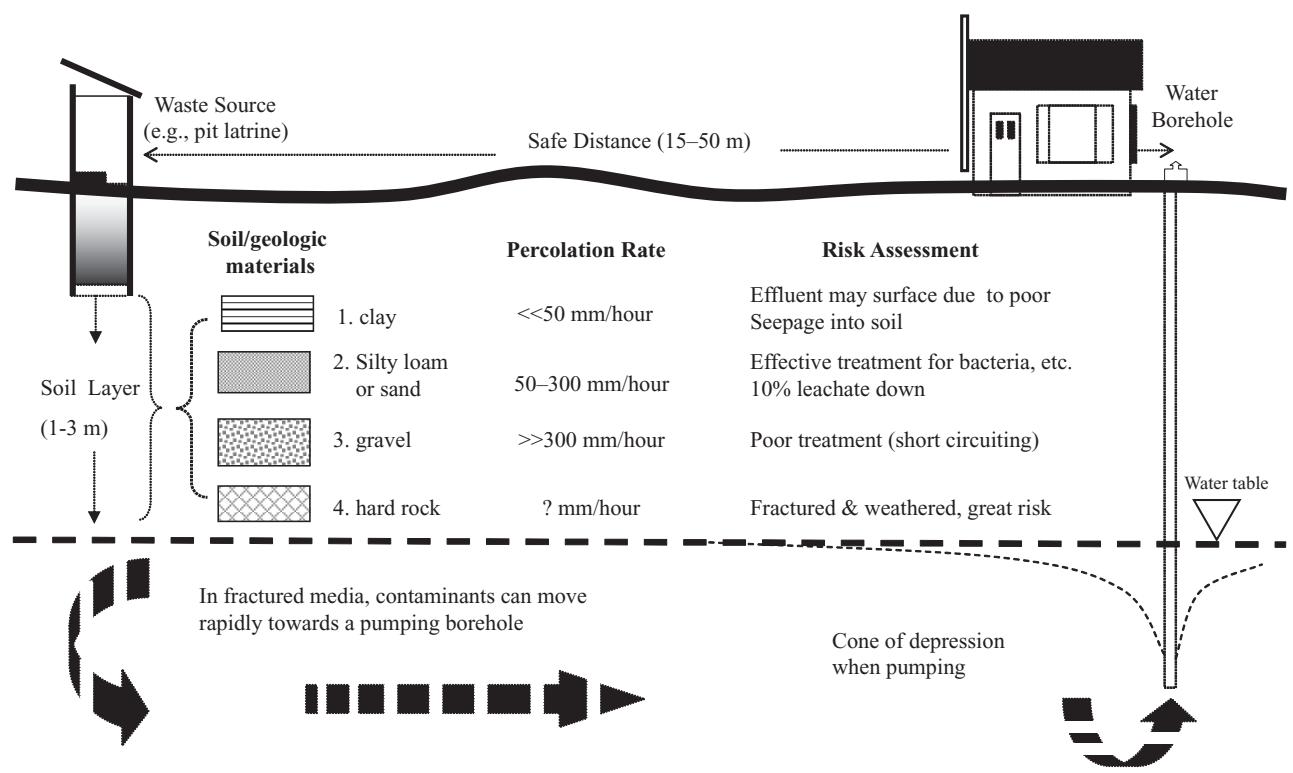

ATTENUATION PROCESSES TAKING PLACE IN SATURATED ZONE

Figure 4.10. A sketch illustrating a on-site sanitation facility and its possible impact on groundwater resource. 
Table 4.9. Types of on-site sanitation and their risk to underlying groundwater.

\begin{tabular}{|c|c|c|}
\hline Type & Discription & $\begin{array}{l}\text { Risk to underlying } \\
\text { groundwater }\end{array}$ \\
\hline Open defacation & $\begin{array}{l}\text { Where there are no latrines people resort } \\
\text { to defecation in the open. This may be } \\
\text { indiscriminate or in special places for } \\
\text { defecation generally accepted by the } \\
\text { community, such as defecation fields, } \\
\text { rubbish and manure heaps, or under trees }\end{array}$ & $\begin{array}{l}\text { Will result in surface water } \\
\text { pollution which can in } \\
\text { turn impact shallow } \\
\text { groundwater }\end{array}$ \\
\hline Simple pit latrine & $\begin{array}{l}\text { A simple wooden or concrete slab over a pit } \\
\text { which may be } 2 \mathrm{~m} \text { or more in depth. The slab } \\
\text { should be firmly supported on all sides and } \\
\text { raised above the surrounding ground so that } \\
\text { surface water cannot enter the pit. If the } \\
\text { sides of the pit are liable to collapse they } \\
\text { should be lined. A squat hole in the slab } \\
\text { or a seat is provided so that the excrete fall } \\
\text { directly into the pit }\end{array}$ & $\begin{array}{l}\text { Does not need water to } \\
\text { function; } \\
\text { The urine plus rainfall plus } \\
\text { flood water ingress can all } \\
\text { contribute to percolation } \\
\text { of contaminants to } \\
\text { groundwater }\end{array}$ \\
\hline $\begin{array}{l}\text { Ventilated pit } \\
\text { latrine }\end{array}$ & $\begin{array}{l}\text { Fly and odour nuisance may be substantially } \\
\text { reduced if the pit is ventilated by a pipe } \\
\text { extending above the latrine roof, with fly- } \\
\text { proof netting across the top. The inside of } \\
\text { the superstructure is kept dark. Such latrines } \\
\text { are known as ventilated improved pit (VIP) } \\
\text { latrines }\end{array}$ & Same as simple pit latrine \\
\hline Pour-flush latrines & $\begin{array}{l}\text { A latrine may be fitted with a trap providing } \\
\text { a water seal, which is cleared of faeces by } \\
\text { pouring in sufficient quantities of water to } \\
\text { wash the solids into the pit and replenish } \\
\text { the water seal. A water seal prevents flies, } \\
\text { mosquitos and odours reaching the latrine } \\
\text { from the pit. The pit can be dug some } \\
\text { distance from the latrine (which could be in a } \\
\text { house) and connected with a pipe or covered } \\
\text { drains. This system could be extended into a } \\
\text { grouped sanitation system }\end{array}$ & $\begin{array}{l}\text { Needs a source of water: } 2-3 \\
\text { litres for each flush; } \\
\text { Increased risk of groundwater } \\
\text { contamination compared } \\
\text { to a pit latrine }\end{array}$ \\
\hline $\begin{array}{l}\text { Single or } \\
\text { double pit } \\
\text { (for both pour- } \\
\text { flush and pit } \\
\text { latrines) }\end{array}$ & $\begin{array}{l}\text { A common practice is to dig a second pit when } \\
\text { the one in use is full to within half a metre } \\
\text { of the slab. If the superstructure and slab are } \\
\text { light and prefabricated they can be moved to } \\
\text { a new pit. The first pit is then filled up with } \\
\text { soil. After two years, faeces in the first pit } \\
\text { will have completely decomposed and even } \\
\text { the most persistent pathogens will have been } \\
\text { destroyed. When another pit is required the } \\
\text { contents of the first pit can be dug out (it is } \\
\text { easier to dig than undisturbed soil) and the } \\
\text { pit can be used again. The contents of the pit } \\
\text { may be used as a soil conditioner }\end{array}$ & $\begin{array}{l}\text { The general tendency is } \\
\text { that more and more pits } \\
\text { are dug, spreading and } \\
\text { increasing the risk of } \\
\text { groundwater contamination }\end{array}$ \\
\hline $\begin{array}{l}\text { ECOSAN latrines } \\
\text { (ecological } \\
\text { sanitation) }\end{array}$ & $\begin{array}{l}\text { Ecosan latrines are latrines that ensure the } \\
\text { recovery of waste by separating urine and } \\
\text { faeces in view of their reuse in the } \\
\text { fertilization of soil for agricultural purposes. } \\
\text { Because of its its many benefits, including a } \\
\text { low impact on groundwater, the Ecosan } \\
\text { approach is discussed in greater detail as a } \\
\text { 'best practice' }\end{array}$ & $\begin{array}{l}\text { Recovery of urine and waste } \\
\text { products; } \\
\text { No pollution of groundwater }\end{array}$ \\
\hline
\end{tabular}


sanitation does not always use the soil as treatment medium (filtration beds, activated sludge are examples of purification systems at the end of the chain).

It is clear from the definition that the boundary between this and off-site sanitation is not always well-identified.

The most used on-site sanitation system in the world is the latrine. It is a site or a structure, located normally outside the house or building, destined to receive and store excreta and sometimes, to process it. This type of sanitation protects sensitive species of aquatic fauna by avoiding discharge concentrations in small waterways. Besides, it is cheaper than off-site sanitation, since the construction of a treatment plant is not required. They can improve living conditions of populations and solve sanitation needs in developing countries. Conventional water-born sewerage systems have been incapable of meeting populations' needs in these countries.

Crucial in any consideration of sanitation options is the question of proper construction and operation and maintenance. A non-functioning conventional sewage works can have a much higher impact on both surface- and groundwater than many pit latrines. Similarly a well chosen, constructed and maintained pit latrine can have minimal effect on local groundwater resources, whereas the same option, poorly executed, can be disasterous. Communities must understand this need of proper implementation in the same way as the upfront considerations like cost and cultural acceptability.

The need for an integrated approach to water supply and sanitation is stressed throughout this publication. An International Symposium on 'Coupling Sustainable Sanitation and Groundwater Protection' held in Hannover, Germany last year has put the focus on this issue and hopefully raised attention.

\subsection{ECOSAN APPROACH FOR EFFECTIVE GROUNDWATER RESOURCES MANAGEMENT}

Ecological sanitation (ecosan) is a new paradigm in the Africa sanitation sector. It recognizes human excreta and household wastewater not as waste but as resources that can be recovered, treated (where necessary), and reused. The concept ecosan focuses on reusing the waste in order to improve health issues, conserve water and other resources as well as protect aquatic ecosystems including groundwater resources. The ecosan approach places an emphasis on cleaning wastes or contaminated flow streams and shifts the concept from waste disposal to resource conservation and safe reuse (UNESCO, 2006). Ecosan is based on an ecosystem approach and treats human urine and faeces as a valuable resource to be recycled. It further shows that ecological sanitation is by no means untried. The needed action is to apply the ecological sanitation concept in existing toilets and wastes in communities and reap the benefits (Esrey et al., 1998).

\subsubsection{Historical context of Ecosan}

The current sanitation paradigm is failing the world, with the poor suffering most, threatening the integrity of fresh water supplies, including groundwater resources. The problems with conventional sanitation are crucial and an alternative approach is imperative. Ecosan provides a guide for improved sanitation by widening access to safe water and sanitation. Ecosan also offers a path out of extreme poverty by providing cheap manure to improve food security in communities. It is a cost effective approach to poverty reduction (UN, 2006). Sub-Saharan Africa remains the area of greatest concern. It is a region of the world where, over the period of 1990-2004, the number of people without access to safe drinking water increased $23 \%$ and the number of people without access to basic sanitation services increased by over $30 \%$. Alternative approaches such as ecosan are needed to ease the situation (WHO \& UNICEF, 2006). 


\subsubsection{Main objective of Ecosan projects}

The main objective of an ecological sanitation system is to protect and promote human health by providing a clean environment and breaking the cycle of disease. In order to be sustainable, an Ecosan system has to be economically viable, socially acceptable, technically and institutionally appropriate, but it should also protect the environment and the natural resources such as groundwater. When improving an existing and/or designing a new Ecosan system, sustainability criteria related to the mentioned aspects need to be taken into consideration (SuSanA, 2007). Generally, objectives of ecological sanitation projects aim at:

- Reducing the health risks related to sanitation, contaminated water and waste

- Preventing the pollution of surface and groundwater

- Preventing the degradation of soil fertility

- Optimizing the management of nutrients and water resources.

\subsubsection{The philosophy about Ecosan}

Ecological sanitation (Ecosan) offers a new philosophy of dealing with what is presently regarded as waste and wastewater. Ecosan is based on the systematic implementation of reuse and recycling of nutrients and water as a hygienically safe, closed-loop and holistic alternative to conventional sanitation solutions. Ecosan systems enable the recovery of nutrients from human faeces and urine for the benefit of agriculture, thus helping to preserve soil fertility, assure food security for future generations, minimize water pollution and recover bioenergy. Ecosan ensures that water is used economically and is recycled in a safe way to the greatest possible extent for purposes such as irrigation or groundwater recharge (Esrey et al., 1998). Ecosan's focus is to:

- Destroy pathogens through flow stream separation, containment and specific treatment

- Conserve resource through a reduced use of potable water as a transport medium for human waste and by recovering wastewater for irrigation

- Reduce/stop wastewater discharges to the environment thereby protecting groundwater

- Close the resource loops through productive use of nutrients contained in excreta.

The new paradigm in sanitation is based on ecosystem approaches. Sanitation systems are part of several cycles, of which the most important cycles are the pathogen-water-nutrientand energy cycle. In order to ensure public health, sanitation approaches primarily aim at interrupting the life cycle of pathogens. In addition, the new approach is recognizing human excreta and water from households not as a waste but as a resource that could be made available for reuse, especially considering that human excreta and manure from husbandry play an essential role in building healthy soils and are providing valuable nutrients for plants.

Ecosan systems restore the natural balance between quantities of nutrients excreted by one person yearly and that required to produce their food $(7.5 \mathrm{~kg}$ nitrate, phosphorous and potassium to produce $250 \mathrm{~kg}$ of grain). In this case ecosan has potential to save limited resources especially in resource poor communities.

\subsubsection{Ecosan and groundwater quality}

With regard to fresh water and mineral resources, Ecosan protects groundwater resources from being polluted by wastes. Ecosan offers desirable solutions, in line with the Bellagio Principles as formulated by the Water Supply and Sanitation Collaborative Council) (UNESCO, 2006). Ecosan approaches strive to enable recovery of nutrients, organic material and water discharged in conventional sanitation systems. Recycling organic material contributes to safeguarding soil fertility and improving its structure and water retention capacity, while 
providing a natural alternative to chemical fertilizers. The process protects the groundwater from being contaminated by chemicals from such wastes. Therefore, Ecosan contributes to enhancing groundwater quality by closing the flow cycle of chemicals from wastes from reaching the groundwater.

\subsubsection{The challenge for Ecosan}

Ecosan approach has potential to become a reliable alternative approach to protecting groundwater resources. However, transmission of relevant knowledge and the existance of well trained people remain a challenge for the science and principles of ecologically sustainable sanitation to be applied in communities to yield its full benefits, including the protection of groundwater resources.

\subsection{COMMUNITY PARTICIPATION BEST PRACTICE}

Groundwater plays an important role in our society and it impacts all aspects of human life. Because of its ubiquitous nature and relative ease of local access, we have widely distributed and generally dispersed abstraction points and have many stakeholders, who are involved in its development, use as well as misuse. This complicates the traditional national approaches to resource regulation and requires a very high degree of participative management. Without this, resource utilization can not be sustainable.

Water resource issues, especially environmental ones, have to involve land use. Largely due to historical reasons, land is owned differently and administered at various levels. Land tenures can vary significantly from one tribe to another and from a country to another. Many stakeholders including the local community may have to be involved in issues like how to manage and protect water resources for a small piece of land in a given community. Furthermore, to have smooth implementation of above identified best practice measures, one cannot ignore the community participation either. In fact, successful management of groundwater resources will often include tales of community participation. Some good cases of participation are provided in this book, for example in spring protection (Section 4.3.6) and field data collection in Benin (Cranel et al., this book). Community participation is the process of learning and coordination by which communities control and deal with data, technology, challenges and development. This is especially critical for any groundwater protection measure that has maintenance and long term sustainability as its objective.

Water user associations, starting at the village level, are a very important way to formalise this participation. The holistic management, stressed previously, of water, land and waste can be put into practice in this way. Key targets of community institutions should be church organisations, tribal authorities, schools and water user organisations, if applicable. These groups have tremendous influence on water source ownership, access and maintenance etc in rural Africa. Non-government-organisations have a major role to play as intermediates between communities and water resource managers and their service providers at different levels. The water science sector should also become much more responsive to community needs and their knowledge and contribution to sustainable development. Some examples of initiatives to formalize community participation and empowerment are:

- EMPOWERS Methods, Tools and Guidelines (Moriarty, 2007);

- Generic Public Participation Guidelines (DWAF, 2001);

- Sustainability Best Practice Guidelines for Rural Water Services (DWAF, 2004);

- Water User Group concept as a sustainable management system for hand pump wells (SKAT, 2001). 


\subsection{TOWARDS A COMPREHENSIVE APPROACH}

Information about implementation of best practice is usually not as well recorded and published as the development of specific scientific elements contributing to it. Therefore one such case, of which the authors are aware, of implementation of a range of best practice is briefly highlighted here. It was an attempt towards a comprehensive approach, and while it got some things right it also suffered a number of fatal flaws. This is the NORAD-Assisted Programme for the Sustainable Development of Groundwater Sources under the Community Water and Sanitation Programme in South Africa (DWAF NORAD, 2004).

The programme, managed by the Department of Water Affairs and Forestry (DWAF) between 2000 and 2004, undertook a series of inter-related projects aimed at enhancing capacity of water services authorities and DWAF to promote and implement sustainable rural water supply schemes based on groundwater resources and appropriate technologies. The activities were piloted in three of the recently established local government districts, located in three of the nine provinces in South Africa.

The programme addressed a national need, because water services had recently been devolved from national to local government level and more than $60 \%$ water supply schemes country-wide were from groundwater sources.

The programme has had an excellent knowledge output in the form of a 'Toolkit for Water Services', with an overall framework, local level strategies and a variety of best practice documentation and softwar (Figure 4.11). It also included a number of reference sites where communities had implemented appropriate technologies. Appendix A shows a full list of the programme outputs (DWAF NORAD, 2004).

\subsubsection{Toolkit for water services}

In the pilot areas of the respective district municipalities the programme had a major impact in introducing appropriate groundwater source management practices and training local personnel. The reference sites included not only groundwater-, but also sanitation best practice.

Successes were due to a number of key factors:

- The development cooperation partner and donor, NORAD, insisted and worked hard to build sustainability into the programme;

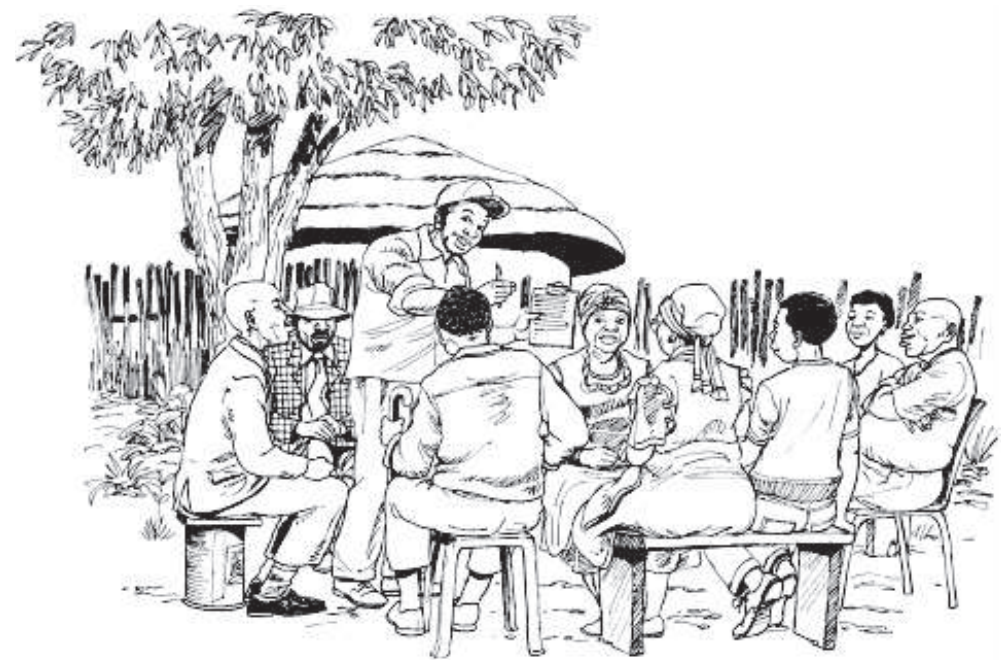

Figure 4.11. A cartoon of community mobilization (DWAF/NORAD, 2004). 
- The programme was enthusiastically driven by the national government institution responsible for water resources, the Department of Water Affairs and Forestry;

- An excellent combination of the best water science (the Council for Geoscience and the Council for Scientific and Industrial Research) and strongest water NGO (Mvula Trust) was acting as implementing agent for the programme;

- NORAD helped to bring international experience into the programme, which was lacking due to South Africa's political isolation before 1994;

- With an inception and an implementation period, the programme stretched over 5 years (2000-2004).

However, the multiplication impact of this intensive programme was limited. Some key reasons for this are summarised below:

- Water Services was a completely new and powerful arm in DWAF, established in response to the post-1994 government priority to address the massive water services backlog in the country. They were deeply committed to a major water services infrastructure development programme (Masibambane programme) and had considerable interest, but little time for a learning initiative, which the DWAF/NORAD Programme was;

- DWAF's lead agent for the Programme was in its existing Water Resource Management arm, through its Directorate Geohydrology. Groundwater was not yet well established as a management responsibility, because under the old water legislation groundwater had been classified as 'private water', and only with the new act, the National Water Act, 1998, was groundwater classified as a 'significant water resource', the same legal status as surface water;

- Programme implementation happened through the DWAF regional offices. At this level, support from the Water Services component, which was the DWAF link to local government, was very difficult to secure under the prevailing priorities;

- District municipalities had no appropriate institutional structures to start accommodating groundwater source management in any sustainable way, and without active involvement of national government Water Services, it was not possible to bring about long-term institutional changes;

- The Programme lost its national champion even before it was completed. With the major restructuring of DWAF in 2003 to support a devolution of water resources management, as foreseen by the National Water Act, 1998, the Directorate Geohydrology was broken up and and functions were integrated, in the spirit of IWRM, into a number of other resource management and assessment functions;

- Without a champion there was no follow up of this strategic initiative.

Also considering discussion in the previous chapters, it is clear that the fatal flaw of this initiative was the lack of an integrated approach between water services provision and resource management.

\section{ACKNOWLEDGEMENTS}

The author gratefully acknowledges the reviews of an early draft of this manuscript by Dr Pete Ashton of the CSIR and Mr Roger Parsons of Parsons and Associates Groundwater Consultants. Their contributions have benefited the final manuscript in terms of both content and relevance.

\section{REFERENCES}

ASTM (2002). ASTM D2855-96. Standard practice for making solvent-cemented joints with poly (vinyl chloride) (PVC) pipe and fittings. DOI: 10.1520/D2855-96R02. ASTM International. West Conshohocken. PA. Accessed on 24/02/2009 at http://www.astm.org/Standards/D2855.htm. 
AWWA (2006). A100-06: AWWA Standard for Water Wells. American Water Works Association. Available from http://www.awwa.org/Bookstore/

Bradbury, K.R. and Muldoon, M.A. (1994). Effects of fracture density and anisotropy on delineation of wellhead protection areas in fractured-rock aquifers. Journal of Applied Hydrogeology, 3/94. pp. 17-23.

Braune, E. and Xu, Y. (2006). A South African perspective on the protection of groundwater sources. In $\mathrm{Xu}$, Y. and Usher, B. eds. (2006). Groundwater Pollution in Africa. Taylor \& Francis/Balkema. pp. 341-349.

BS (1988). BS 879-2:1988. Water well casing. Specification for thermoplastics tubes for casing and slotted casing. British Standards. ISBN 0-580-16488-8.

BWA (2009). Standard form drilling agreement. Borehole Water Association of Southern Africa. Available at http://www.bwa.co.za/

Calow, R.C., MacDonald, A.M., Nicol, A.L. and Robins, N.S. (2009). Ground water security and drought in Africa: linking availability, access and demand (In press). Ground Water.

Calow, R.C., Robins, N.S., MacDonald, A.M., Macdonald, D.M.J., Gibbs, B.R., Orpen, W.R.G., Mtembezeka, P., Andrews, A.J. and Appiah, S.O. (1997). Groundwater management in drought prone areas of Africa. International Journal of Water Resources Development, 13, 2, 241-261.

Chave, P., Howard, G. and Schijven, J. (2006). Groundwater protection zones. In: Schmoll, O., Howard, G., Chilton, J. (eds) Protecting groundwater for health. World Health Organisattion, IWA Publishing, London.

Clay, E., Borton, J., Dhiri, J., Gonzalez, A.D.G. and Pandolfi, C. (1995). Evaluation of ODA's response to the 1991-1992 Southern African drought. ODA Evaluation Report EV 568. UK Department for International Development, London.

Driscoll, F.G. (ed.) (1986). Groundwater and Wells. 2nd edition. Johnson Division. St. Paul. Minnesota. ISBN 0-9616456-0-1.

Driscoll, F.G. (ed.) (2008). Groundwater and Wells. 3rd edition. Johnson Division. St. Paul. Minnesota. ISBN 0-9787793-0-4.

DWAF (1997). A protocol to manage the potential of groundwater contamination from on site sanitation. National Sanitation Co-ordination Office, Department of Water Affairs and Forestry, Pretoria. First edition published in 1997.

DWAF (2001). Generic Public Participation Guidelines. Department of Water Affairs and Forestry.

DWAF (2003). A protocol for the protection of groundwater from contamination from sanitation practices. National Sanitation Co-ordination Office, Department of Water Affairs and Forestry, Pretoria. Second edition published in 2003.

DWAF (2004). Sustainability Best Practice Guidelines for Rural Water Services. No. 7.1, Toolkit for Water Services. NORAD-assisted Programme for Sustainable Development of Groundwater Sources under the Community Water and Sanitation Programme in south Africa.

DWAF/NORAD (2004). NORAD-Assisted Programme for the Sustainable Development of Groundwater Sources under the Community Water and Sanitation Programme in South Africa. Pretotia: Department of Water Affairs and Forestry.

Entrepeneur.com (2009). Maintenance for wells and boreholes. Accessed on 16/02/2009 at https://www. entrepreneur.com/tradejournals/article/146063295.html.

EPA (1975). Manual of water well construction practices. Document 570975001 accessed on 22/02/2009 at http://nepis.epa.gov/EPA/html/Pubs/pubtitleOSWER.htm. Last updated on 15/10/2007.

Esrey, S.A., Gough, J., Rapaport, D., Sawyer, R., Simpson-Hébert, M., Vargas, J. and Uno Winblad (ed) (1998). Ecological Sanitation; Swedish International Development Cooperation Agency, Department for Natural Resources and the Environment, Stockholm, Sweden.

FCI (2004). Borehole and hand pump implementation, operation and maintenance. A manual for field staff of NGO's. Foundation (Stichting) Connect International in collaboration with WES Consultants (Uganda). Accessed on 16/02/2009 at http://www.connectinternational.nl/english/ smartmodules/smart-tec/wells-boreholes/conventionaldrilling.

Ferro, B.P.A. and Bouman, D. (1987). Explanatory notes to the hydrogeological map of Mozambique scale 1:1,000,000. Ministry of Construction and Works. National Directorate for Water Affairs. Mozambique.

Focazio, M.J., Reilley, T.E., Rupert, M.G. and Helsel, D.R. (2002). Assessing ground-water vulnerability to contamination: Providing scientifically defensible information for decision makers. U.S. Geological Survey Circular 1224. (available online as http://pubs.usgs.gov/circ/2002/circ1224/)

Foster, S., Hirata, R. and Games, D. et al. (2002). Groundwater quality protection - a guide for water utilities, municipal on authorities, and environment agencies. Groundwater Management Advisory Team, The World Bank, Washington. 
Foster, S., Hirata, R., Gomes, D., D’Elia, M. and Paris, M. (2007). Groundwater quality protection: a guide for water utilities, municipal authorities, and environment agencies. The World Bank Publication, ISBN 0-8213-4951-1, Whashington, DC 20433, USA.

Foster, S., Tuinhof, A. and Garduño, H. Task Manager: David Grey (World Bank-AFR), (2006). Groundwater Development in Sub-Saharan Africa: A Strategic Overview of Key Issues and Major Needs, World Bank.

Ginsberg, M. and Palmer, A. (2002). Delineation of Source-water Protection Areas in Karst Aquifers of the Ridge and Valley and Appalachian Plateaus Physiographic Provinces: Rules of Thumb for Estimating the Capture Zones of Springs and Wells. Publication EPA 816-R-02-015, U.S. Environmental Protection Agency. p. 41.

Gogu, R.C. and Dassargues, A. (2000). Current trends and future challenges in groundwater vulverability assessment using overlay and index methods. Environmental Geology 39 (6): 549-559.

Gotkowitz, M.B. and Gaffield, S.J. (2006). Water-table and aquifer-susceptibility maps of Calumet County, Wisconsin. Miscellaneous Map 56, Wisconsin Geolgical and Natural History Survey, University of Wisconsin-Extension.

Harvey, C. (2004). 1.72, Groundwater Hydrology, Lecture Packet \#6: Groundwater-Surface Water Interactions, http://www.myoops.org/cocw/mit/Civil-and-Environmental-Engineering/1-72Fall-2004/ LectureNotes/index.htm.

Hobbs, P.J. and Marais, S.J. (1997). Minimum standards and guidelines for groundwater resource development for the community water supply and sanitation programme. 1st edition. Department of Water Affairs and Forestry. Pretoria. South Africa.

Howard, G., Mutabazi, R. and Nalubega, M. (2000). Rehabilitation of protected springs in Kampala, Uganda, Water, sanitation and hygiene: chanllenges of the Millennium, 26th WEDC Confereence, Dhaka, Bangladesh, 2000.

Hussey, S.W. (2007). Water From Sand Rivers, Guidelines for Abstraction. Water, Engineering and Development Centre, Loughborough, UK.

IRC (2004). What is on-site sanitation? A case study of latrines. A fact sheet prepared by CREPA, Burkina Faso. IRC International Water and Sanitation Centre, The Hague.

Javandel, I. and Tsang, C. (1986). Capture-zone type curves: A tool for aquifer cleanup, Ground Water, 24(5): 616-625.

Jolly, J.L. and Reynders, A.G. (1993). The protection of aquifers: a proposed classification and protection zoning system for South African conditions. An International Groundwater Convention Entitled 'Africa needs groundwater' at the University of the Witwatersrand, Johannesburg, South Africa, 6-8 September 1993.

Lawrence, A.R., Macdonald, D.M.G., Howard, A.G., Barrett, M.H., Pedley, S., Ahmed, K.M and Nalubega, M. (2001). Guidelines for assessing the risk to groundwater from on site sanitation. Technical Report British geological Survey CR/01/142. Available from http://www.bgs.ac.uk/hydrogeology/argoss/docs/ARGOSSManual_144.pdf.

Lifewater (2004). Drilling and well construction manual. Version http://www.lifewater.ca/ndexdril.htm. Accessed on 16/02/2009 at http://www.lifewater.ca/resources/drillingtutor.htm

Louw-Carstens, M. (2008a). Stryd om kind in gat te red (E. Battle to save child in hole). Beeld Newspaper. Accessed on 25/02/2009 at http://www.news24.com/Beeld/Suid-Afrika/0,3-975_2420616,00. html.

Louw-Carstens, M. (2008b). Boorgat: 'Mens verwag dit nie' (E. Borehole: 'One doesn't expect it'). Beeld Newspaper. Accessed on 25/02/2009 at http://www.news24.com/Beeld/Suid-Afrika/0,3-975_ 2421032,00.html.

LWBC (2003). Minimum construction requirements for water bores in Australia. 2nd edition. Land and Water Biodiversity Committee. ISBN 1-9209-2009-0.

MacDonald, A., Davies, J., Calow, R. and Chilton, J. (2005). Developing Groundwater-A guide for Rural water supply, ITDG Publishing, UK, 2005, ISBN 185339 596X.

MacDonald, A., Davies, J., Calow, R. and Chilton, J. (2005). Developing Groundwater, A Guide for Rural water Supply. ITDG Publishing, Warwickshire, UK.

McCarthy, P. (2008). The insidious nature of groundwater contamination - the great need for protection. Presentation at International Symposium on 'Coupling Sustainable Sanitation and Groundwater Protection', Hannover, 14-17 October 2008.

McDonald, M.G. and Harbaugh, A.W. (1988), A modular three-dimensional finite difference groundwater flow model: Techniques of Water-Resources Investigations of the U.S. Geological Survey, Chapter A1, Book 6. 
Minnesota Department of Health (2005). Guidance for delineating wellhead protection areas in fractured and solution-weathered bedrock in Minnesota. Report prepared by the Minnesota Department of Health, Drinking Water Protection Section, Source Water Protection Unit. p. 80.

Moriarty, P., Batchelor, C., Abd-Alhadi, F.T., Laban, P. and Fahmy, H. (2007). The EMPOWERS Approach to Water Governance: Guidelines, Methods, Tools. EMPOWERS Partnership, Amman, Jordan.

Mwami, J. (1995). Spring protection - sustainable water supply, Sustainability of water and sanitation systems, 21st WEDC conference, Kampala, Uganda, 1995.

Nel, J.M., Xu, Y., Batelaan, O. and Brendonck, L. (2009). "Benefit and implementation of groundwater protection zoning in South Africa", Water Resource Manage (2009) DOI 10.1007/s11269-009-9415-4, Springer.

NWQMS (1995). National water quality management strategy: guidelines for groundwater protection in Australia. Department of Primary Industries and Energy, Agriculture and Resource Management Council of Australia and New Zealand, Canberra.

PIPA (2007a). Industry guidelines: PVC pipe equivalence. Issue 1.0. Plastics Industry Pipe Association of Australia Limited. Available from http://www.pipa.com.au/PVCs.html\#POP104.

PIPA (2007b). Industry guidelines: PVC pipes in bore casings. Issue 1.0. Plastics Industry Pipe Association of Australia Limited. Available from http://www.pipa.com.au/PVCs.html\#POP105.

Pochon, A., Tripet, J.P., Kozel, R., Meylan, B., Sinreich, M. and Zwahlen, F. (2008). Groundwater protection in fractured media: a vulnerability-based approach for delineating protecion zones in Switzerland, Hydrogeology Journal. V.16., No 7. 1267-1281.

Rayne, T.W., Bradbury, K.R. and Muldoon, M.A. (2001). Delineation of capture zones for municipal wells in fractured dolomite, Sturgeon Bay, Wisconsin, USA. Hydrogeology Journal. V.9., No. 5. 432-450.

SADC (2000a). Standards and guidelines for the groundwater development in the SADC region. Report No. 2. Groundwater Consultants for SADC Water Sector Coordination Unit. Maseru. Lesotho.

SADC (2000b). Situation analysis report. Report No. 1. Groundwater Consultants for SADC Water Sector Coordination Unit. Maseru. Lesotho.

SADC WSCU ( 2000). Guidelines for Groundwater Development in the SADC Region, SADC Water Division, Gobarone, Botswana.

Sami, K. and Murray, E.C. (1998). Guidelines for the evaluation of water resources for rural development with an emphasis on groundwater. Report no. 677/1/98. Water Research Commission. Pretoria.

SANS (2003a). SANS 10299-2:2003. Development, maintenance and management of groundwater resources-Part 2: The design, construction and drilling of boreholes. Standards South Africa. ISBN 0-626-14790-5.

SANS (2003b). SANS 10299-9:2003. Development, maintenance and management of groundwater resources-Part 9: The decommissioning of water boreholes. Standards South Africa. ISBN 0-626-14803-0.

SAPPMA (2006). Technical manual. 1st edition. Southern African Plastic Pipe Manufacturers Association. Available at http://www.sappma.co.za/pdfs/SAPPMA_TM_LR.pdf.

Sheik, M., Gutierrez, M.I., Bolton, P., Spiegel, P., Thieren, M. and Burnham, G. (2000). Deaths among humanitarian workers. British Medical Journal. Volume 321. pp. 166-168.

SKAT (2004). The Shinyanga Experience: Water User Group concept as a sustainable management system for hand pump wells. Tanzania Ministry of Water and Livestock Development with the Government of the Netherlands and Swiss Centre for Development Cooperation in Technology and Management.

Spangler, L.E. (2002). Use of dye tracing to determine conduit flow paths within source-protection areas of a karst spring and wells in the Bear River Range, Northern Utah. In: Proceedings, U.S. Geological Survey Karst Interest Group, U.S. Geological SurveyWater-Resources Investigations Report 02-4174. 75-80.

SuSan, A. (2007). Joint roadmap for the promotion of sustainable sanitation in the UN's "International Year of Sanitation 2008"- draft".

UN (2006). Hashimoto Action Plan: Compendium of Actions: United Nations Secretary-General's Advisory Board on Water and Sanitation.

UNEP (1996). Groundwater: A threatened resource, UNEP Environment Library No. 15, Nairobi, UNEP, 1996.

UNESCO (2006). Capacity building for ecological sanitation: Concepts for ecologically sustainable sanitation in formal and continuing education, UNESCO Working Series SC-2006/WS/5, Paris, France. 
USEPA (1987). Guidelines for Delineation of Wellhead Protection Areas: U.S. EPA Office of GroundWater Protection, Chapters paginated separately.

USEPA (1991). Delineation of Wellhead Protection Areas in Fractured Rocks. U.S. EPA Technical Guidance Document, by K.R. Bradbury, M.A. Muldoon and A. Zaporozec. U.S. EPA Office of Groundwater, EPA 570/9-91-009, p. 144.

Usher, B.H., Pretorius, J.A. and Dennis, I. et al. (2004). Identification and prioritisation of groundwater contaminants and sources in South Africa's urban catchment. WRC report 1326/1/04. Water Research Commission, Pretoria.

Vias, J.M., Andreo, B., Perles, M.J., Carrasco, F., Vadillo, I. and Jimenez, P. (2006). Proposed method for groundwater vulnerability mapping in carbonate (karstic) aquifers: the COP method. Hydrogeology Journal, 14: 912-925.

Vinidex (2004). Technical Note: PVC pipes under external pressure. No. VX-TN-4F.2. Available at http://www.vinidex.com.au/vinidex/live/RESOURCES/IMAGES/technotes/TN-4F.2.2004PVCpipes underexternalpressure.pdf.

WHO (1992). A Guide to the Development of on-site Sanitation. Geneva: World Health Organization.

WHO and UNICEF (2006). Meeting the MDG drinking water and sanitation Target. The urban and rural challenge of the decade, Geneva, Switzerland.

Worthington, S.R.H., Smart, C.C. and Ruland, W.W. (2002). Assessment of groundwater velocities to the municipal wells at Walkerton. In: Ground and Water: Theory to Practice: Proceedings of the 55th Canadian Geotechnical and 3rd Joint IAH-CNC and CGS Groundwater Specialty Conferences, Niagara Falls, Ontario, October 20-23, 2002. Edited by D. Stolle, A.R. Piggott and J.J. Crowder and published by the Southern Ontario Section of the Canadian Geotechnical Society. pp. 1081-1086.

Xu, Y. and Braune, E. (1995). A guideline for groundwater protection for the Community Water Supply and Sanitation Programme. Department of Water Affairs and Forestry, Pretoria.

Xu, Y. and Reyders, A.G. (1995). A three-tier approach to protect groundwater resources in South Africa, ISSN 0378-4738, Water SA, Vol. 21 No. 3 July 1995.

$\mathrm{Xu}, \mathrm{Y}$. and Usher, B. (2006). Issues of groundwater pollution in Africa. In Xu, Y. and Usher, B. eds. (2006). Groundwater Pollution in Africa. Taylor \& Francis/Balkema. pp. 3-9.

\section{APPENDIX A: CONTENT OF TOOLKIT FOR WATER SERVICES \\ (DWAF NORAD, 2004)}

\section{Overview Documentation}

1.2 Implementing a Rural Groundwater Management System: a step-by-step guide

\section{Descriptors}

2.1 Standard Descriptors for Geosites

3 Groundwater Protection

3.1 Involving community members in a hydrocensus

3.2 Guidelines for protecting springs

3.3 Guidelines for protecting boreholes and wells

3.4 Guidelines on protecting groundwater from contamination

3.4.1 Animal kraals, watering points and dipping tanks

3.4.2 Burial sites

3.4.3 Informal vehicle servicing, spray painting and parts washing facilities

3.4.4 Pit latrines

3.4.5 Runoff water

3.4.6 Subsistence agriculture

3.4.7 Informal waste disposal

\section{Maps}

4.1 Thematic Groundwater Maps

\section{Software}

5.1 Sustainability Indexing Tool (SusIT)

5.1.1 SusIT User Guide

5.1.2 SusIT Field Data Capturer's User Manual 
5.1.3 SusIT Questionnaire

5.1.4 SusIT Information Brochure

5.2 AquiMon Management System

5.2.1 AquiMon Information Brochure

5.3 Geohydrological Data Access System (GDAS)

5.3.1 GDAS Information Brochure

6 Monitoring

6.1 Groundwater Monitoring for Pump Operators

7 Sustainability

7.1 Sustainability Best Practices Guidelines for Rural Water Services

7.2 Introductory Guide to Appropriate Solutions for Water and Sanitation

7.3 Decision Making Framework for Municipalities

\section{Reference Sites}

8.1 Genadendal Information Brochure

8.2 Kammiesberg Information Brochure

8.3 Maputaland Information Brochure. 